\title{
Problém účelnosti v dialogickém vyučování
}

\author{
ZuZana Šalamounová, KLÁRa ŠEĎOVÁ, \\ MarTin SEDLÁČEK, Roman ŠVAŘíčEK
}

\begin{abstract}
Abstrakt: Př́spèvek vycházi z dat ziskaných v rámci intervenčního výzkumného projektu, $v$ nèmž skupina učitelù prošla programem profesního rozvoje zaměreným na to, aby byli učitelé s to implementovat do své výuky postupy tzv. dialogického vyučování. Dialogické vyučováni, které tvoŕi teoretickou platformu této studie, je prístup, který usiluje o komunikační i kognitivni aktivizaci žákù (Alexander, 2006). Intervence se ukázala jako úspěšná v tom smyslu, že došlo ke zmènè komunikačního chováni učitelì i jejich žákù ve sledovaných tř́dách. V prüběhu analýzy dat jsme si však povšimli, že u v̌̌ech učitelu docházi k porušováni principu účelnosti. V teorii dialogického vyučováni se pritom operuje s nutnosti dodržet tzv. princip účelnosti (tamtéz)), jimž je minèno směrováni jednotlivých aktivit a učebnich úloh smèrem k vytčenému cíli, kterým je zprostredkovávat žákưm obsahy a praktiky konstituujicí učivo daného predmètu (Herbel-Eisenmann, Steele \& Cirillo, 2013).

$V$ tomto príspěvku se nejprve zamérujeme na to, jakou podobu maji bezúčelné pasáže identifikované ve vyučovacích hodinách. Představujeme typologii situací, v nichž docházi $k$ porušení účelnosti, a popisujeme, čim toto porušeni vzniká. Hovořime o kategorii hádáni tématu, kvazi-evokace a kvazi-reflexe, sousedského kláboseni, zadáni mimo dosah žákỉ a digresi do osobního života žákì. Jakožto príčiny vzniku bezúčelných pasáži popisujeme nezacílené prevzetí výukových metod a odklon výuky od piovodního plánu výuky, který učitel neni s to zvrátit. Následnè sledujeme vztah mezi klícovým indikátorem žákovských replik s argumenty a naplnovánim účelnosti, abychom zjistili, jak prítomnost dialogického vyučováni souvisi s účelnosti výuky. $Z$ našich nálezů pritom vyplývá, že pokud dochází k posilováni indikátoru žákovských replik s argumenty, docházi také k posilování účelnosti.
\end{abstract}

Kličová slova: dialogické vyučováni, princip účelnosti, bezúčelnost výuky, obsah výuky, žákovské repliky sargumenty, intervenčni program pro učitele.

\section{1. ÚvoD}

Tento př́spěvek vychází z dat získaných $\mathrm{v}$ rámci intervenčního výzkumného projektu, $\mathrm{v}$ němž skupina učitelů prošla programem profesního rozvoje zaměřeným na to, aby učitelé byli $s$ to implementovat do své výuky postupy tzv. dialogického vyučování. Námi realizovaná intervence se ukázala jako úspěšná v tom smyslu, že došlo ke změně komunikačního chování učitelů i jejich žáků ve sledovaných třídách. Učitelé se naučili klást žákům ote- 
vřené otázky vyšší kognitivní náročnosti, navazovat na žákovské promluvy a rozvíjet je. Žáci začali ve zvýšené míre formulovat propracované promluvy obsahující argumentaci, klást otázky a reagovat $\mathrm{v}$ diskusi na promluvy svých spolužáků (Šed’ová et al., 2014, 2016a).

Všechny výše uvedené jevy jsou považovány za charakteristické indikátory dialogického vyučování a jejich posilování je chápáno jako žádoucí. Nabízí se však otázka, zda soustředění na indikátory coby formální znaky dialogu nevede do pasti formalismu. Nedochází v dialogickém vyučování k tomu, že žáci hovoří rozvitě a reagují na sebe navzájem, avšak bez jasného vztahu $\mathrm{k}$ učivu a kurikulu? $\mathrm{V}$ teorii dialogického vyučování se operuje s nutností dodržet tzv. princip účelnosti (Alexander, 2006). Účelnost v tomto smyslu znamená směřování jednotlivých aktivit a učebních úloh směrem $\mathrm{k}$ vytčenému cíli, jímž je zprostředkovávat žákům obsahy a praktiky, které konstituují učivo daného předmětu (Herbel-Eisenmann et al., 2013). Bez napojení na učivo dialog nemůže být účelný.

$\mathrm{V}$ průběhu analýzy dat získaných v rámci našeho výzkumného projektu jsme si povšimli, že u všech učitelů (v různé miŕe) dochází k porušování principu účelnosti. Cílem tohoto príspěvku je proto s ohledem na princip účelnosti systematicky analyzovat data z výuky učitelů, kteří prošli intervenčním programem na podporu dialogického vyučování. Klademe si otázku, jaký je charakter bezúčelných pasáží a zda lze jejich výskyt připisovat snaze o zavedení dialogického vyučování do výuky.

\section{TEORETICKÁ VÝCHODISKA}

\subsection{Dialogické vyučování, jeho indikátory a principy}

Dialogické vyučování je takový typ komunikace mezi učitelem a žáky, při němž dochází ke komunikační i kognitivní aktivizaci žáků, $\mathrm{k}$ podněcování jejich myšlení a prohlubování porozumění (Alexander, 2006). Koncept dialogického vyučování má své zázemí v sociokulturní teorii, reprezentované zejména Vygotským (1978). Základem je přesvědčení o úzkém vztahu mezi řečí, myšlením a učením. Proponenti dialogického vyučování nahlížejí na učení nikoli jako na osvojování určité znalosti, nýbrž spíše jako na participaci v určitém diskurzu (viz např. Sfard, 2008). V dialogickém vyučování jsou žáci různými způsoby povzbuzováni $\mathrm{k}$ tomu, aby rozvitým způsobem vyjadřovali své myšlenky. Tím dochází k intenzivní kognitivní stimulaci. Zároveň jsou žáci v takto pojatém vyučování angažovaní, je jim dopřána značná autonomie a mohou do určité míry ovlivňovat dění v hodině (srov. Alexander, 2006; Lyle, 2008; Reznistkaya \& Gregory, 2013).

Teorie dialogického vyučování je poměrně bohatá a její součástí jsou různé konceptuální nástroje, které umožňují posoudit, do jaké míry je charakter výuky dialogický. Mezi těmito nástroji dominují indikátory a principy (viz napr. Alexander, 2006). Indikátory jsou pozorovatelné jevy, které signalizují př́tomnost dialogického vyučování. V námi realizovaném programu profesního vzdělávání jsme pracovali s následujícími indikátory: 1. učitelské otevrené 
otázky vyšši kognitivni náročnosti (Gayle, Preiss \& Allen, 2006) - otázky učitele, na které není předem daná správná odpověd' a které vyžadují od žáků vyšší kognitivní operace, než je zapamatování; 2. uptake - situace, kdy učitel na žákovskou promluvu reaguje položením rozvíjející otázky, stimulující další elaboraci promluvy (Nystrand et al., 1997); 3. pokládáni otázek žáky (Nystrand et al., 2001); 4. triadická interakce - struktura, v níž na sebe navzájem reagují nejméně tř̌i mluvčí (Molinari \& Mameli, 2013); 5. komplexni žákovské promluvy s argumentací (Pimentel \& McNeill, 2013) - promluvy, které mají charakter věty a zároveň zahrnují zdůvodňování či logickou argumentaci.

Tyto indikátory, stejně jako některé další, bývají používány při popisu dialogického vyučování, zaznívají však také hlasy, že samotná přítomnost indikátorů není zárukou dialogické povahy vyučování (viz např. Boyd \& Markarian, 2011, 2015). Alexander (2006) uvádí, že indikátory představují vodítko, avšak rozhodující je základní epistemologie výukové interakce. Proto Alexander (tamtéž) navrhuje sadu princip̊̊, tedy zásad, jimiž se učitelé $\mathrm{v}$ dialogickém vyučování musí ř́idit: 1. kolektivita - do výukové komunikace se mají zapojit pokud možno všichni žáci; 2. reciprocita - učitelé a žáci si mají vzájemně naslouchat a sdílet své myšlenky a názory; 3. podpuirnost - ve tř́́dě je nastolena svoboda vyjádřit vlastní myšlenky bez obav z nesprávné odpovědi či zesměšnění; 4. kumulativnost - komunikace má směrovat $k$ postupné kumulaci znalostí pomocí postupných na sebe navazujících kroků;
5. účelnost - interakce je podřízena stanoveným vzdělávacím cílům.

$\mathrm{V}$ dialogickém vyučování by mělo docházet $\mathrm{k}$ harmonické symbióze mezi indikátory a principy. Jde však o velmi komplexní úkol, jehož dosažení je pro běžné učitele patrně velmi obtížné (Lefstein, 2010). Podle Alexandera (2006) je v dialogickém vyučování obzvláště obtížné dosáhnout těch principů, které se týkají obsahu komunikace, tedy principů kumulativnosti a účelnosti. Hammondová (2016) vnímá vztah mezi formou a obsahem v dialogickém vyučování jako potenciálně problematický. Jde o to, aby se soustředění na interakční struktury a formy nestalo samoúčelným, nýbrž reálně vedlo $k$ podpoře žákovského učení určitých kurikulárních obsahů, což je problém, na který se v této studii soustředíme.

\section{2 Účelnost ve výuce}

Žáci se do školy chodí učit. Aby $\mathrm{k}$ tomu mohlo dojít, musejí mít př́ležitost pracovat $\mathrm{s}$ výukovým obsahem takovým způsobem, který povede $\mathrm{k}$ dosažení výukových cílů, a to za vhodné podpory ze strany učitele (Janík et al., 2013, s. 155). Jinými slovy, jednotlivé aktivity, na nichž žáci ve výuce participují, musejí směřovat $\mathrm{k}$ vytčenému cíli, přičemž tímto cílem je zprostředkovávat žákům obsahy a praktiky, které konstituují učivo daného předmětu. Teprve pokud výuka s tímto požadavkem koresponduje, lze ji podle Herbel-Eisenmanna et al. (2013) chápat jako výuku, která naplňuje výše popsaný princip účelnosti. Při uvažování o účelnosti výuky je 
tedy kladen důraz na provázání s obsahy a postupy konkrétního předmětu, na disciplinaritu.

Jak vyplývá z výše uvedeného, každý vyučovací předmět má své oborově specifické obsahy (reprezentované pojmy jednotlivých předmětů a jejich vzájemnými vztahy, viz Lemke, 1990) a praktiky, které utvářjí jeho učivo. Stejně tak tomu je i v př́padě vyučovacích předmětů, do nichž bylo situováno naše výzkumné šetření (literární složka českého jazyka a literatury, dále jen literární výchova a občanská výchova). Je samozřejmé, že obě uvedené výchovy se od sebe v mnohém odlišují. Za nejobecnější cíle literární výchovy lze považovat rozvíjení čtenářských návyků a schopnosti tvořivé recepce, interpretace a produkce literárního textu s cílem ovlivnit postoje žáků, jejich hodnotové orientace a obohatit jejich duchovní život (RVP ZV, 2007, s. 20, dále s. 23-24). $V$ prŕpadě multidisciplinární občanské výchovy, resp. výchovy k občanství, by pak bylo možné na nejobecnější rovině hovořit o výchově k odpovědnému lidství, vlastenectví a občanství (Pitha et al., 1992, s. 8n., viz také RVP ZV, 2007, s. 57-61). Spojnici mezi oběma nicméně vytváŕí skutečnost, že literární i občanská výchova se jakožto humanitní předměty ${ }^{1}$ zabývají různými aspekty života člověka (Průcha, Walterová \& Mareš, 2009, s. 93) a obě usilují o návaznost učiva na zkušenostní svět žáků. Hník (2015) v rámci didaktiky literární výchovy hovoří o žádoucím propojení výuky literatury s žákovskou čtenářskou zkušeností, Staněk (2007) pak jako východisko občanské výchovy udává konkrétní témata co nejbližší životu žáků, od nichž je teprve možné postupovat $\mathrm{k}$ tématům abstraktnějším. Obě disciplíny tak mají evidentně blízko $\mathrm{k}$ tzv. vstřícnému pojetí kurikula (Maňák, 2007, s. 44). V popředí stojí žákovské zkušenosti, které v interakci s edukační situací ovlivňují obsah a metody výuky a podmiňují induktivně vytvárené vzdělávací cíle.

Dialogické vyučování samo o sobě inklinuje ke vstřícnému pojetí kurikula, nebot́ zpětné extrahování cílů až při zohlednění žákovských zkušeností je v souladu $s$ jeho požadavkem, aby výuka, její obsah, metody i cíle byly otevřeny myšlenkám žáků. Mohli bychom tedy hypoteticky předpokládat, že literární i občanská výchova budou uplatnění dialogického vyučování více otevřeny nežli předměty, pro něž je typické racionální, zprostředkující pojetí kurikula. $\mathrm{Na}$ druhou stranu však mohou být oba sledované předměty ze stejného důvodu více otevřeny didaktickému formalismu (Hejný \& Kuřina, 2009, s. 149), tedy nemoci kognitivní struktury, která narušuje účelnost výuky. Máme na mysli didaktický formalismus označovaný jako tzv. utajené poznávání (Janík et al., 2013, s. 236), které se vyznačuje tím, že vyučovací a učební aktivity žákům skrývají souvislost $s$ instrumentální praxí oboru, tj. s odborným oborovým jednáním, myšlením a jazykem, resp. symbolikou předmětu. Myšlenkové procesy žáků

${ }^{1}$ Jsme si vědomi toho, že občanská výchova bývá začleňována také pod předměty společenskovědní, viz Staněk, 2015. 
v tomto př́ípadě nejsou napojeny na rozvíjení oborových pojmů, takže před žáky zůstává skryto, jaká je spojitost mezi aktivitami, které ve výuce probíhají, a učivem. $\mathrm{K}$ tomuto typu formalismu se vyjadřuje také Štech (2003, s. 84), který uvádí: „Děti sice prožívají radost nebo napětí, to však ještě neznamená, že poznání bude v takové situaci hlubší nebo kvalitnějšši." Výuka, v nîž dochází $\mathrm{k}$ utajenému poznávání, tedy žáky může bavit, nicméně negarantuje, že se jejím prostřednictvím něco naučí, nebot spojitost $s$ učivem je pro ně nejasná.

Mezi didaktickými formalismy se vedle utajeného poznávání dále uvádí tzv. odcizené poznávání (Janík et al., 2013, s. 236). Podoba výuky, pro kterou je charakteristické odcizené poznávání, je zpravidla taková, že učitel nahrazuje poznávací činnosti žáků vlastním výkladem, požaduje od žáků místo objevitelského prrístupu převzetí předpřipravených tezí, žákovské chyby vnímá jako problém, a nikoli jako prŕležitost $\mathrm{k}$ učení. $\mathrm{V}$ důsledku tohoto nastavení výuky pak žáci pouze mechanicky reprodukují poznatky, ale neučí se (a z možnosti pochybení se často i bojí) samostatně oborově myslet. Je zřejmé, že popsaný typ formalismu a uspořádání výuky je $\mathrm{v}$ rozporu s metodou dialogického vyučování stejně jako s cíli obou sledovaných výchov. Pokud by totiž literární výchova i občanská výchova probíhaly ve shodě $s$ obecně stanovenými cíli a oborově didaktickými doporučeními (vycházely by ze zkušeností žáků), lze předpokládat, že riziko výskytu tohoto typu formalismu narušujícího účelnost výuky je minimální. Oborové didaktiky literární i občanské výchovy jakožto vědecké disci- plíny se však teprve etablují (Hník, 2014; Staněk, 2015), takže výraznější empirickou oporu pro tento předpoklad nemáme.

Hovořili jsme o cílech výuky občanské a literární výchovy a jejich důsledcích pro uvažování o účelnosti výuky. Cíle výuky se nicméně vztahují také $\mathrm{k}$ rozvíjení nejobecnějších žákovských dispozic (kompetencí), které překračují hranice jednotlivých předmětů a lze je považovat za nadoborové, interdisciplinární. Také $\mathrm{v}$ tomto př́padě ovšem platí, že rozvoj kompetencí se odvíjí od oborově specifického učiva. Pro zachycení těchto poměrně složitých vztahů navrhli Slavík et al. (2014) obecný, nadoborový schematický model výuky, který obsahuje trri vrstvy: tematickou, konceptovou a kompetenční. Ústřední je konceptová vrstva, která reprezentuje strukturu konceptů př́islušného vědního oboru včetně specifických činností. Tematická vrstva znamená konkretizaci konceptů skrze napojení na každodenní žákovské zkušenosti. Kompetenční vrstva pak obsahuje generalizované cíle rozvoje dispozic $\mathrm{k}$ učení, komunikaci a myšlení. Kvalitní výuka má být podle autorů integrovaná - má zabezpečit provázání mezi všemi třemi vrstvami, umožňovat mezi nimi přechody prostřednictvím abstrakce a generalizace. Jak je z tohoto modelu evidentní, také interdisciplinární cíle se vždy odvíjejí na platformě oborového poznání.

\section{Metodologie}

V letech 2013-2015 jsme realizovali dvě vlny intenzivního vzdělávacího programu pro učitele druhého stupně základ- 
ní školy s cílem přibližit jejich výukovou praxi ideálu dialogického vyučování. Programu se zúčastnilo celkem osm učitelů. $\mathrm{Z}$ toho čtyři vyučovali český jazyk a literaturu, čtyři občanskou výchovu. Realizovaný vzdělávací program sestával z několika komponent: 1. workshopy pro učitele; 2. dokumentování výuky pomocí videonahrávek; 3. reflektivní rozhovory vedené ve dvojici výzkumník-učitel nad videonahrávkami jednotlivých lekcí. Průběh projektu zachycuje schéma $v$ př́loze 1). Logika celého postupu byla taková, že učitelé byli na workshopech seznámeni s teoretickým pozadím konceptu dialogického vyučování a jeho principy (workshop 1) a dále s jeho klíčovými indikátory a metodami, jak jich dosahovat (workshop 2 byl věnován učitelským otázkám a poskytování uptake, workshop 3 byl věnován žákovským otázkám a triadické interakci). Workshop 4 byl závěrečný a sloužil ke sdílení zkušeností $s$ projektem.

Jednotlivé workshopy vždy ústily v kolaborativní diskusi o tom, jaké výukové metody ve třídě používat, aby bylo dosaženo vytčených indikátorů a zároveň byly zachovány principy dialogického vyučování. S návrhy přicházeli jak výzkumníci, tak samotní učitelé, kteří přemýšleli o tom, jak v kontextu dialogického vyučování využít postupy, se kterými již byli obeznámeni a které běžně používali. Lze říci, že se vzdělávací program koncentroval na tři elementy dialogického vyučování: indikátory, principy a metody. Zatímco to, o jaké indikátory a principy se bude v projektu usilovat, bylo předem určeno a bylo to dáno záměrem výzkumníků, element metod byl do programu zakomponován mnohem volněji a byl ponechán do značné míry na vůli jednotlivých učitelů. Šlo o to, aby všichni směřovali $\mathrm{k}$ implementaci týchž indikátorů a principů, avšak za využití různých výukových metod.

Mezi jednotlivými workshopy učitelé realizovali běžnou výuku ve svých třídách, do níž se snažili zapojovat prvky dialogického vyučování. Výzkumníci docházeli do škol a pořizovali videonahrávky výuky. V̌sechny snímané lekce trvaly 45 minut. Každý učitel pracoval ve dvojici s jedním výzkumníkem. Ten pořizoval videonahrávky a následně vybíral sekvence pro reflektivní rozhovory stimulované videonahrávkami. Tyto rozhovory obvykle trvaly 45-60 minut a jednak se soustřed'ovaly na to, zda byly jednotlivé indikátory učitelem pochopeny a implementovány správně, jednak sloužily k obecnější reflexi toho, zda je postup učitele v souladu s epistemologií dialogického vyučování a zda dochází $\mathrm{k}$ naplňování principů dialogického vyučování (Alexander, 2006). V rámci těchto rozhovorů také docházelo $\mathrm{k}$ vytváření plánů pro následující vyučovací hodinu.

\section{1 Účastníci výzkumu}

Spolupracovali jsme s osmi učiteli druhého stupně základní školy a jejich třídami. Jednalo se o zkušené a motivované učitele, kteří se sami dobrovolně přihlásili na naši výzvu. Výzva byla omezena na vyučující předmětů český jazyk a literatura a občanská výchova. Tímto omezením jsme chtěli předejít př́lišné heterogenitě vzorku a také usnadnit sdílení zkušeností mezi partici- 
Tab. 1. Účastníci výzkumu ${ }^{2}$

\begin{tabular}{|l|c|c|c|c|c|}
\hline Učitel & $\begin{array}{c}\text { Délka } \\
\text { praxe }\end{array}$ & Vyučovaný předmět & Ročník & $\begin{array}{c}\text { Počet žáků } \\
\text { ve tř́dě }\end{array}$ & Škola \\
\hline Jonáš & 6 let & český jazyk a literatura & 7 & 21 & škola A \\
\hline Radek & 8 let & občanská výchova & 9 & 22 & škola A \\
\hline Hana & 20 let & český jazyk a literatura & 7 & 18 & škola B \\
\hline Václav & 3 roky & občanská výchova & 9 & 20 & škola C \\
\hline Marcela & 22 let & občanská výchova & 8 & 26 & škola C \\
\hline Daniela & 11 let & český jazyk a literatura & 7 & 20 & škola D \\
\hline Marek & 12 let & český jazyk a literatura & 7 & 19 & škola E \\
\hline Martina & 5 let & občanská výchova & 7 & 19 & škola E \\
\hline
\end{tabular}

pujícími učiteli. Všechny školy, na nichž jsme výzkum prováděli, jsou situovány v Jihomoravské kraji. Tři z těchto škol se nacházejí ve velkém městě, jedna $\mathrm{v}$ malém městě a jedna na vesnici. Charakteristiky jednotlivých učitelů zachycuje tabulka 1 .

\subsection{Data a jejich analýza}

V průběhu projektu jsme shromáždili rozsáhlý datový korpus, který zahrnuje videonahrávky lekcí, audionahrávky individuálních rozhovorů s učiteli realizovaných po jednotlivých lekcích, plány učitelů pro jednotlivé lekce ve formě stručných rukou psaných poznámek, audionahrávky skupinových diskusí na workshopech a dotazníky a testy pro žáky. $V$ této studii pracujeme především $s$ daty $\mathrm{z}$ videonahrávek výuky a také $s$ daty $\mathrm{z}$ audionahrávek individuálních reflektivních rozhovorů. Od každého učitele máme $\mathrm{k}$ dispozici sérii devíti po sobě jdoucích videonahrávek, které dokumentují postupnou implemen- taci změn, a zároveň sérii reflektivních rozhovorů pořízených mezi jednotlivými videonahrávkami (viz schéma $\mathrm{v}$ př́loze 1 ). Kromě toho jsme při práci na této studii využili učitelské plány výuky, a to při kódování datového materiálu (viz dále).

Veškeré videonahrávky byly přepsány do podoby transkriptů a podrobeny kvantitativní i kvalitativní analýze. $\mathrm{V}$ prvním kroku jsme vyšli z kvantitativního sledování hodnot indikátorů dialogického vyučování. Pro všechny sledované vyučovací hodiny u obou učitelů jsme spočítali výskyt vybraných indikátorů, přičemž jsme sledovali, zda $\mathrm{v}$ průběhu projektu docházelo $\mathrm{k}$ jejich nárůstu, stagnaci či poklesu. Postup při kódování jsme popsali v již publikované knize (Šed'ová et al., 2016b). Jako klíčový jsme identifikovali indikátor žákovských promluv $s$ argumentací, který podle nás nejlépe vystihuje dialogickou povahu výukové komunikace (tamtéž). Žákovskou promluvou s argumentací máme na mysli

${ }^{2}$ Jména učitelů jsou pseudonymy. 
žákovské vyjádření kompletní myšlenky (strukturou blízké větě či větám), která obsahuje také zdůvodnění či argumentaci (Pimentel \& McNeill, 2013).

$\mathrm{V}$ této studii se vydáváme za hranice indikátorů a soustředíme se na princip účelnosti. Veškerý materiál $\mathrm{z}$ videonahrávek jsme podrobili novému kódování zaměřenému na rozlišení účelnosti a neúčelnosti výuky. Nejprve byly všechny lekce rozděleny do epizod (viz Lehesvuori et al., 2013; Lehesvuori \&Viiri, 2015). Epizoda pro nás představuje základní analytickou jednotku, jde o odlišitelnou část $\mathrm{v}$ rámci vyučovací hodiny, která sestává z konkrétní aktivity, má své téma, je charakterizovaná jedním konzistentním cílem. Ukončení epizody nastává se změnou aktivity, tématu nebo komunikačního př́stupu, což zároveň znamená začátek další epizody.

$\mathrm{K}$ dělení lekcí na epizody jsme přistoupili z toho důvodu, že ne všechny části lekcí představovaly vhodný materiál pro analýzu. Po rozdělení na epizody jsme dále pracovali pouze $s$ epizodami, $v$ nichž docházelo $\mathrm{k}$ interakci mezi učitelem a tř́ídou jako celkem - vyloučili jsme např́klad epizody, jejichž předmětem bylo předčítání textu, samostatná práce, skupinová práce. Jednotlivé vyučovací hodiny ve vzorku obsahovaly různý počet epizod, průměrně šlo o 4,5 epizody na hodinu. Do analýzy bylo zahrnuto celkem 220 epizod z celkového počtu 335.

Kódovali jsme transkripty jednotlivých epizod. Postupovali jsme řádek za řádkem a identifikovali jsme, co je účelné, podle toho, zda je daná pasáž v souladu s výukovými cíli učitele zachycenými v plánu učitele pro danou lekci a/nebo $s$ nadřazenými předmětovými cíli vymezenými v rámcových a školních vzdělávacích programech. Posoudit, zda je určitá pasáž účelná, či neúčelná, se ukázalo jako náročný úkol. Proto jsme celý materiál podrobili vícenásobnému kódování, jehož schéma je zachyceno níže (obr. 1). Veškeré rozdíly mezi jednotlivými kódéry byly řešeny diskusemi nad transkripty, které

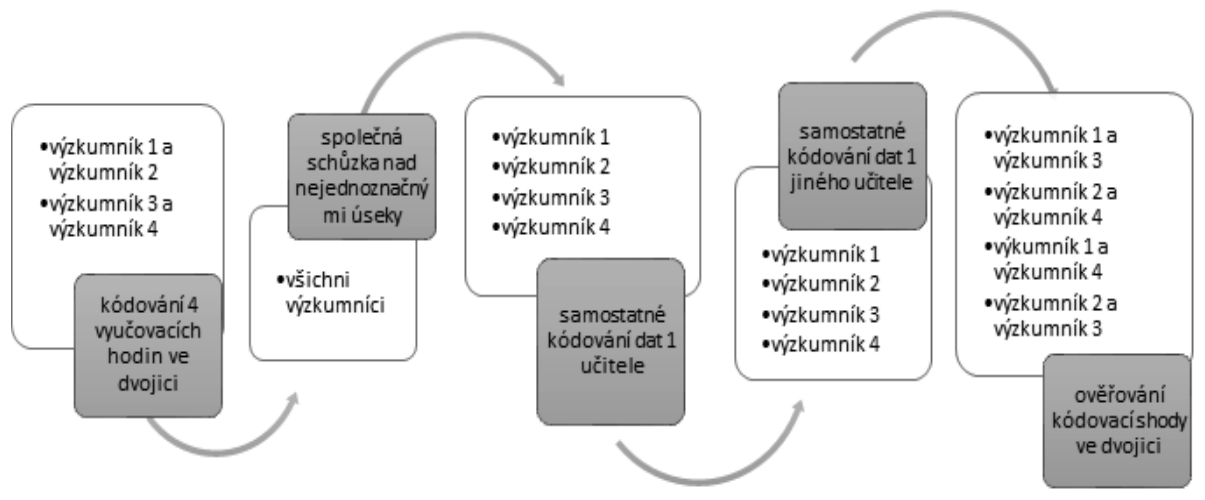

Obr. 1. Proces kódování 
vedly ke vzájemnému konsenzu. Nepostupovali jsme tedy tak, že bychom celé epizody trrídili na účelné či neúčelné, ale zaměřovali jsme se na to, co v dané pasáži koresponduje $s$ výukovými cíli, a co naopak výuku zastavuje, nebo přímo odvádí do slepé uličky.

Ve výsledku došlo $\mathrm{k}$ vytř́ídění materiálu do dvou kategorií - oddělili jsme pasáže účelné a neúčelné. Postupovali jsme přitom tak, abychom si byli jisti, že mezi účelnými pasážemi je opravdu pouze to, co lze jednoznačně považovat za účelné. Pasáže, jejichž status byl nejasný či nejednoznačný, jsme řadili do kategorie neúčelných, a to především proto, abychom je nevyloučili z další fáze analýzy, jíž bylo třídění bezúčelných pasáží na různé typy. Jakožto neúčelné jsme dále kódovali všechny interakce, které prímo nesouvisejí $s$ výukovým obsahem - např́klad disciplinační či osobní. Pokyny učitele, jimiž ř́dil práci žáků na učebních úlohách, byly kódovány jako účelné, avšak v př́padě, že docházelo $\mathrm{k}$ jejich opakování, byly již při svém druhém a dalším výskytu kódovány jako neúčelné.

\subsection{Výzkumné otázky a analytické postupy}

V tomto př́spěvku si klademe dvojí cíl: jednak chceme typologizovat situace, $\mathrm{v}$ nichž dochází $\mathrm{k}$ narušení účelnosti, identifikovat a interpretovat jejich zdroje, jednak chceme zjistit, jaký je vztah mezi formálními dialogickými indikátory a účelností. Jestliže dochází $\mathrm{k}$ posilování indikátorů, dochází také $\mathrm{k}$ posilování účelnosti? Nebo je př́tomen opačný vztah a dochází $\mathrm{k}$ oslabování účelnosti a tedy k vyprazdňování obsahu? Klademe si proto následující výzkumné otázky: 1 . Jaký je charakter bezúčelných pasáží, které jsme identifikovali ve výuce participujících učitelů? 2. Jak učitelé výskyt bezúčelných pasáží vysvětlují? 3. Jaký je vztah mezi mírou účelnosti výuky a výskytem žákovských promluv s argumentací?

Odpověd' na první výzkumnou otázku jsme hledali prostřednictvím otevřeného kódování a následné kategorizace všech pasáží vyučovacích hodin, které byly označeny jako neúčelné. Rozlišili jsme pět typů bezúčelných aktivit, které podrobně popisujeme v kapitole 4. Pro zodpovězení druhé výzkumné otázky bylo nutné analyzovat reflektivní rozhovory vedené s učiteli. Zaměrili jsme se na ta místa $\mathrm{v}$ rozhovorech, kde učitelé zdůvodňovali, proč zařadili do výuky různé typy aktivit. Především jsme sledovali, jak učitelé hovoří o těch pasážích výuky, které byly v našem kódování identifikovány jako neúčelné. Pro výskyt těchto bezúčelných pasáží jsme nalezli dvě různá vysvětlení, která představujeme v kapitole 5 . Třetí výzkumná otázka si žádala kvantitativní analýzu. Naprŕíc všemi epizodami jsme sledovali vztah mezi dvěma proměnnými - výskytem žákovských promluv s argumentací a množstvím účelně využitého času v dané epizodě. Žákovské promluvy s argumentací chápeme jako klíčový formální indikátor dialogického vyučování, množství účelně využitého času pro nás reprezentuje míru naplnění principu kolektivity. $\mathrm{K}$ měřní vztahu jsme použili Pearsonův korelační koeficient. 


\section{VÝSLEDKY VÝZKUMNÉHO ŠETŘENí}

Veškeré bezúčelné pasáže jsme po jejich identifikaci podrobili dalšímu tř́iění. $\mathrm{Z}$ analýzy jsme $\mathrm{v}$ této fázi vyloučili krátká odbočení od tématu hodiny ( $\mathrm{v}$ řádu sekund), jež mají organizační či disciplinační charakter. Tyto „vsuvky“ považujeme za nezbytné, nebot v zásadě umožňují, aby se učitel a třída mohli zabývat učivem.

Kódovali jsme pouze dlouhé kompaktní pasáže, které se zcela odklánějí od výukového cíle i od nadřazených předmětových cílů. Jako minimální práh pro to, aby daná pasáž vstoupila do tř́dění, jsme určili 30 sekund trvání. Další podmínkou bylo, aby dané pasáže neměly organizační či disciplinační charakter, nýbrž byly součástí didaktického plánu učitele pro danou hodinu. Jak ukážeme dále, výskyt těchto pasáží $\mathrm{v}$ našem datovém materiálu lze připsat snaze učitele realizovat dialogické vyučování. Neznamená to však, že by se tyto pasáže objevily ve výuce jen $\mathrm{v}$ důsledku intervenčního programu. Řadu aktivit tohoto typu učitelé realizovali již dříve $\mathrm{v}$ přesvědčení, že tímto způsobem dosahují diskuse se žáky. Stejný způsob práce pak využili také $\mathrm{v}$ rámci programu s tím, že tak budou vhodně naplňovat jeho cíle. Učitelé tedy $\mathrm{v}$ rámci bezúčelných pasáží dělají vše pro to, aby naplnili dialogické indikátory dialogického vyučování (at již svým osvědčeným, nebo novým postupem), avšak bez jasného vztahu k učivu a kurikulu. Jaké jsou typy těchto záměrně realizovaných, nicméně bezúčelných pasáží, si představíme dále.

\subsection{Typy bezúčelných pasáží}

\subsubsection{Bezúčelné hádanky}

Prvním reprezentantem neúčelných pasáží jsou tzv. bezúčelné hádanky. Jedná se o situace, $\mathrm{v}$ nichž učitel žákům klade otázku, jejíž úspěšné zodpovězení negarantuje vybavení správné odpovědi (jako tomu je u otázek nižší kognitivní náročnosti) ani vyvolání náročnějších myšlenkových operací (jako u otázek vyšší kognitivní náročnosti). Jedinou správnou odpověd' totiž zná učitel sám a na žácích je, aby uhodli, co má na mysli. Pouze hádání tedy může vést $k$ úspěšnému zodpovězení otázky. Typický př́klad představují situace, kdy mají žáci uhodnout téma hodiny.

\section{Ukázka $1:^{3}$}

Učitel Marek ve výuce literárni výchovy otevirá téma stredověku a hodlá začit problematikou rytîrství. Na počátku vyučovací hodiny se žáků ptá, která skupina obyvatel mèla zvláštni privilegia:

1. Učitel: Tak, ted' zkusíme, se podívat na určitou skupinu obyvatel, kteří (.) nebo skupinu obyvatel, občanů, kteři měli ve středověku nějaká zvláštní privilegia. Ta privilegia vycházela z jejich povinností.

2. Hugo: Jakože král?

3. Učitel: Tak, třeba král. To je jedna (ukazuje na ruce) z obyvatel, jedna ze skupin obyvatel středověku. Vašku?

${ }^{3}$ Značky v přepisech jsou vysvětleny v príloze 2 . 
4. Vašek: Prostý člověk.

5. Učitel: Prostí lidé, ti měli také, ale neměli jich moc, těch privilegií. Hmm? ( $u k a ́$ že na Oldricha)

6. Oldřich: Kněží.

7. Učitel: Kněží.

8. Vašek: Vojáci?

9. Učitel: Nějací vojáci. Katka? (ukazuje na Katku)

10. Katka: Židi?

11. Učitel: Židé (1) ve středověku v Evropě stáli na okraji, protože Židé byli lidi, kteří měli obrovské problémy ve spojitosti $s$ ukřižováním a tak dále. A ještě jedna skupina lidí?

12. Oldřich: Šlechta.

13. Učitel: Tak, šlechta. Šlechta se vzala odkud, ve středověku?

14. Oldřich: (blásíse) Já vím, z těch (.) lidí, co byli (.) jako u (n). Oni byli zprvu vojáci, dostávali majetky, (.) a potom ty majet-, $\mathrm{v}$ těch majetcích, to bylo něco jako (.) města [U: Třeba, děkuju.] a oni jim platili (.) daně třeba.

15. (...)

16. Kamila: No, ochutnávači jídel.

17. Učitel: Jaké ti měli velké právo?

18. Kamila: No když někdo, když někdo prinesl jídlo, tak ho ochutnali, aby nebylo otrávené.

19. Katka: Takže vlastně (n).

20. Učitel: To bylo jejich právo, nebo jejich povinnost?

21. Oldřich: Povinnost.

22. Kamila: Povinnost.

23. Učitel: To znamená, moje otázka původně ale byla o právech. Skupina lidí, kteři měli speciální práva.

24. Oldřich: Rolník, (.) ne?
25. Učitel: (usmivá se) No, skoro ses trefil. 26. Oldřich: Pracující člověk.

27. Učitel: Tak, koho, koho posílali na draka králové?

28. Slávek: (vykrikuje) Prince.

29. Hugo: (vykrikuje) Honzu.

30.Slávek: (vykřikuje) Bajaja.

31. Katka: Tovaryše.

32. Učitel: Tovaryše, ježkovy zraky, vy jste to úplně (n). Tak, (1) o králi Artušovi jste doufám slyšeli.

33.Žáci: (šum)

34. Oldřich: Jo, skupina lidí, kouzelníci.

35. Učitel: Tak, můžeme? (.) Tak, král Artuš měl kolem sebe skupinu lidí.

36. Natka: Shrek.

37. Učitel: Shreka kolem sebe, Natko, neměl.

38.Žáci: (smich, šum)

39. Učitel: Tak, můžeme? (.) Jakou skupinu lidí měl kolem sebe král Artuš, kteří mu radili, vydávali se na dobrodružné výpravy? 40. Oldřich: (vykřikuje) Jeho družinu.

41. Učitel: Šššs, budeme se hlásit a nebudeme překřikovat.

42. Hugo: Vojevůdce?

43. Učitel: Ten tam byl taky, ale ne (n). (ukazuje na Oldricha)

44. Oldřich: Jeho družina.

45. Učitel: Tak, a jeho družinu tvořila jaká skupina obyvatel?

46. Žáci: (překřikuji se) Tovaryši.

47.Učitel: Ššš (dává znameni, aby se ztišili). Ondro, (ukazuje na něj) všichni ho poslouchejte.

48. Ondra: Rytî́i?

49.Učitel: Děkuji. Tak, budem se, dneska jsem se zrovna chtěl bavit na téma rytíri. 
Jak dokládá první řádek ukázky, samotné učitelovo zadání by mohlo odpovídat otázkám vyšší kognitivní náročnosti a ve výuce by mohlo být účelné - žáci by mohli uvádět jednotlivé skupiny obyvatel a argumentovat, jaké měly práva a povinnosti, čímž by postupně mohl vzniknout obraz složení středověkého obyvatelstva. Interakce je však podřizena tomu, že žáci hádají téma hodiny - požadovaná odpověd' je pouze jedna jediná a předem daná učitelem. Spojitost s privilegii a povinnostmi je spiše př́iležitostná (řádek 5 a 16-21), načež vymizí docela. Bez ohledu na to, že žáci ve svých prvních odpovědích prokazují, že jsou s to vhodně odpovídat na položenou otázku (uvedením krále, šlechty a duchovenstva totiž vyjmenovali privilegované vrstvy obyvatelstva), $\mathrm{k}$ uhodnutí správné odpovědi to nestačí. $\mathrm{V}$ důsledku toho se celá sekvence stále více přibližuje tipovací soutěži. Interakce končí sadou nápověd typických pro pasáže založené na hádání, jimiž se učitel snaží žákům $\mathrm{k}$ odpovědi dopomoci (např́íklad řádek 26, kde se učitel ptá, koho králové posílali na draka, nebo řádek 31, kde učitel konstatuje, že žáci snad již slyšeli o králi Artušovi). I použité nápovědy však žáky ve sledované ukázce vedou na scestí, protože žákovské konotace se zcela liší od těch, které očekává učitel (žáci by na draka místo rytî́r̊ poslali Honzu či prince, viz rádky 27-30, a krále Artuše mají na základě série kreslených pohádek spojeného mimo jiné se zeleným zlobrem Shrekem, řádek 35).

V celé ukázce bychom našli dílčí interakce, které lze charakterizovat jako účelné. Když např́klad žákyně Kamila navrhuje ochutnavače jídel, vede jí učitel k odlišení práv a povinností (řádky 15-21). Stejně tak když žákyně Katka navrhuje Židy, učitel tuto miskoncepci částečně opravuje (řádky 10 a 11). Jedná se však o ojedinělé, situačně vzniklé interakce, které učitelem nejsou plánované a nejsou s to zvrátit charakter celé aktivity.

Tipovací aktivity založené na hádání slova, které má učitel na mysli, současně dokumentují nedostatečnou práci s pojmy. Učitel neprovázal žáky nabízené pojmy vojáci, př́ipadně šlechta s požadovaným slovem rytírí, přestože mezi nimi lze najít pojmovou blízkost (rytírská jízda u nás byla jádrem středověkého vojska zhruba do husitské doby). Z ukázky je tedy evidentní, že žáci měli uhodnout jedno předem dané, konkrétní slovo (rytírii) spíše než objekt, který toto slovo označuje (válečník šlechtického původu zasazený do období středověku). Hledání jednoho slova namísto objektu, který může být pojmenován vícero způsoby, hádankový charakter tohoto typu pasáží ještě více podtrhuje.

Hádat však žáci nemusejí pouze téma hodiny. U učitelky Hany např́íklad žáci tipují, kdo by mohl být Bella a kdo Sebastián ve stejnojmenném románu Cécile Aubryové, u učitelky Marcely mají žáci pro změnu hádat napríklad to, kdy mohla být přijata Všeobecná deklarace lidských práv (žáci se přitom o všeobecné deklaraci doposud nebavili a dataci si dříve neuváděli, takže si na ni nemohou vzpomenout, v dějepise doposud 20. století neprobírali).

Bezúčelnost popsaných situací je tedy dána těmito znaky: a) žáci nemají možnost, jak na odpověd' prijíít, vyjma mechanismu 
hádání, z čehož vyplývá i druhý znak: b) pokud by učitel odpověd' rovnou řekl sám, žáci by z hlediska své další kognitivní práce nebyli o nic ochuzeni, nebot' se z postupu hádání nemají co naučit, musejí se pouze trefit. Pokud by se navíc učitelé rozhodli namísto žákovského hádání odpověd' sami sdělit, nedošlo by ke zbytečné časové ztrátě. Např́klad žáci učitele Marka v uvedené ukázce touto aktivitou strávili 13 minut.

\subsubsection{Kvazi-evokace a kvazi-reflexe}

Jak již název tohoto typu bezúčelných pasáží napovídá, jedná se o postupy inspirované konstruktivistickým, třífázovým modelem učení jdoucím od evokace přes uvědomění $\mathrm{k}$ reflexi, obecně známým pod zkratkou E-U-R. Cílem evokace je vyvolat žákovské prekoncepty související s tématem, které je v hodině probíráno. Jde o aktivitu, která slouží jako předehra k aktivitě následující a ve vztahu $\mathrm{k}$ dalšímu průběhu hodiny může být velmi účelná, nebot učiteli umožňuje identifikovat žákovské prekoncepty a navázat na ně $\mathrm{v}$ dalším procesu učení. Stejně významné opodstatnění má také reflexe, nebot $v$ jejím průběhu žáci třídí a systematizují nově nabyté informace, uchopují je vlastními slovy a současně si uvědomují hranice nově poznaného. $V$ našich datech se však (vedle účelných evokačních a reflektivních pasáží) objevovaly také evokace a reflexe zařazené do výuky bezprizorně. Jejich uplatnění bylo z hlediska napojení na výukové cíle bezúčelné, a proto je označujeme jako kvazi-evokace a kvazi-reflexe.

Zastavme se nejprve u kvazi-evokací. $\mathrm{V}$ účelných evokačních pasážích šlo ob- vykle ve shodě se smyslem metody evokace o to, aby si žáci vybavili, co již o dané problematice vědí, príípadně aby prezentovali zkušenosti, které byly následně učitelem využity při výkladu nové látky. Pasáže, které jsme $\mathrm{v}$ analýze identifikovali jako neúčelné, však tyto rysy postrádaly. Naopak se u nich objevovaly následující charakteristiky: 1. souvislost $s$ probíranou látkou byla pouze asociativní; 2 . jakmile byla evokace ukončena, již se $\mathrm{k}$ ní dále $\mathrm{v}$ hodině neodkazovalo, žádné další komunikované obsahy na ni nebyly napojovány.

\section{Ukázka 2:}

$V$ hodině občanské výchovy probirá učitelka Marcela se žáky téma státnich symbolu. Učitelka: Já vám vždycky řeknu slovo (1) a vy se pokusíte (.) nakreslit $\mathrm{k}$ tomu slovu symbol. A prosím, není to na známky a já bych chtěla, abyste nekoukali k sousedům, (1) abyste se nedomlouvali a abyste nakreslili ten svůj symbol podle sebe. Tak (2), takže, řeknu slovo, kreslís symbol. Rozumíme? (1) Láska.

1. Žáci: (kresli symbol do sešitu)

2. Učitelka: Smutek.

3. Žáci: (kreslí symbol do sešitu)

4. Učitelka: Radost.

5. Standa: Co?

6. Učitelka: (opakuje) Radost. Namaluj symbol.

7. Standa: Já nevím na smutek.

8. Učitelka: Takže láska, smutek, radost. (vypočitává na prstech) (1) Smrt.

9. Žáci: (kreslí symbol do sešitu)

10. Učitelka: (opakuje) Smrt. (rozhliži se po trídè) Láska, smutek. (1) Tak, (1) stačí. Co láska? 
11.Žáci: (vykřikuji) Srdíčko.

12. Učitelka: Má někdo něco jiného?

13. (nikdo se nehlási)

14. Učitelka: Jak to, že všichni máte namalované srdíčko? Vy jste se domlouvali?

15.Žáci: Ne.

16. Učitelka: Jak jste to věděli?

17. Míša: To bylo logický, protože (.) protože se říká, (.) protože se říká, že když jako někdo někomu jakože zlomí srdce třeba, jo, tak jakoby...

18. Učitelka: Aničko, jakou tam vidíš tu logiku v lásce.

19. Anička: Tak to je jako kdyby symbol jako té lásky.

20. Učitelka: A co kdybych řekla infarkt?

(1) Kdybys namalovala srdce. (1) Jak bys poznala?

21. Míša: Mozek. (ukazuje si na hlavu)

22. Anička: Tak tam bude mrtvej člověk.

23. Učitelka: Přeškrtla, přeškrtla bys to. Ještě někdo? Jak jste věděli, že máte namalovat srdce (.) u lásky.

24. Míša: Protože to cítíme.

25. Učitelka: Používá se to. Je to, (.) některé ty symboly jsou běžně užívány mezi lidmi a všichni je v tomhle tom (.) významu používáme. Stejně tak si troufnu tvrdit, (.) že u té smrti budete mít křrižek. Je to pravda?

26. Žáci: Jo.

27. Učitelka: (prikyvuje) Máte ho tam všichni. A taky jsme se nedomlouvali (.) Že, Eliško. (divá se na ni) $\mathrm{Na}$ té smrti (1), všichni máme křížek a nedomluvili jsme se na tom. (.) To znamená, některé ty symboly jsou obecně uznávané, obecně používané a my je známe. A ted'ka, téma dnešní hodiny, napište si tam prosím nadpis, Aničko, státní symboly.
Aktivita má povahu hry s překvapením - ačkoli žáci mohou nakreslit cokoli, zjistí, že jejich obrázky jsou shodné. Úkolem žáků je doplnit grafickou asociaci k zadaným pojmům. Následně jsou v duchu logiky dialogického vyučování vyzváni, aby vysvětlili, proč zvolili dané obrázky. Nejpropracovanější odpověd’ nabízí Miša již na řádku 17, kde poukazuje na souvislost obrázku s obecně používanými úslovími. Učitelka však tuto odpověd' nekomentuje a ponechává ji bez povšimnutí. Následuje odpověd' kruhem (řádek 19) a dále odpověd', v níž se na argumentaci a logické vysvětlování rezignuje (řádek 24). Odpovědi žáků mají tedy spišse sestupnou tendenci, než že by docházelo $\mathrm{k}$ postupné konstrukci nové znalosti. Vyústěním celé sekvence je teze, že symboly jsou sdílené (jsou obecně uznávané, obecně použivané a my je známe), kterou vyslovuje sama učitelka na řádku 27 bez toho, že by jakkoli navazovala na žákovské př́spěvky. Pokud by tento závěr byl dále $\mathrm{v}$ hodině zužitkován a byl využit jako součást definice státních symbolů, mohla by být aktivita účelná. $\mathrm{K}$ tomu však v hodině nedošlo. Po dokončení aktivity se učitelka již nevracela ani k použitým př́kladům (obrázky srdce či kř́ǐ̌e), ani ke sdílenosti jako rysu státních symbolů. Spojitost mezi obecnými symboly a státními symboly zůstala pro žáky skrytá.

Analogickým př́íkladem kvazi-evokace je situace $\mathrm{z}$ výuky učitele Jonáše, který žákům rozdal obrázek F. Villona a chtěl, aby mu žáci sdělovali, co lze z obrázku o autorovi vyčíst. S žákovskými odpověd’mi se však dále nijak nepracovalo, aktivita nebyla napojena na další činnosti ve vyučovací hodině a vyzněla zcela do prázdna. 
Podobě nejasným vyzněním, jakým působí kvazi-evokace, je poznamenán také postup vzdáleně se podobající závěrečné fázi modelu E-U-R, o němž hovoříme jako o kvazi-reflexi. Reflexe má žáky vést $\mathrm{k}$ tomu, aby si uvědomili, jakého posunu dosáhli (at už se zaměŕíme na obsah učení, nebo jeho proces), což vyžaduje čas pro přemýšlení žáků. Kvazi-reflexi však tyto charakteristiky chybí. Žáci nejsou vedeni $\mathrm{k}$ tomu, aby přemýšleli nad tím, co nového se dozvěděli, ani jak to souvisí s tím, s čím do výuky vstupovali. Př́íkladem může být pasáž z výuky učitelky Hany:

\section{Ukázka 3:}

$V$ hodinè literatury vedené učitelkou Hanou vypracovávaji žáci tzv. pétilistek. Jde o grafické schéma, $v$ nèmž žáci pèti rüznými zprisoby s použitím presnè daného počtu slov (jedno až čtyři) a presně daných slovnich drubů (podstatná jména, prídavná jména, slovesa) zaznamenávaji námèt textu. Hana żákưm zadala, že první slovo pètilistku má být šoa.

1. Učitelka: A poslední věc, kterou uděláte, tak si uděláte pětilístek.

2. Žáci: Néé.

3. (...)

4. Učitelka: Každý sám, nebavte se. A komu se to podaří, tak se prihlaste, at se zkusíme, jak se vám to podařilo a jestli aspoň jste porozuměli. (4) Máš to, Peto?

5. Petr: Já nevím.

6. (Žáci pracuji, z chodby je slyšet hluk prestávky.)

7. Učitelka: Nesmí se ta slova opakovat, ano, to víme. (5) Tak kdo má aspoň ten začátek? Kdo má ta př́ídavná jména?

\section{Alena: Krutý}

9. Učitelka: Krutý, výborně.

10. Tereza: Strašný

11. Učitelka: Jak? Strašný.

12. Patrik: Malý.

13. Učitelka: Prosím? (Směrem k Honzovi, který dává najevo zájem komunikovat.)

14. Honza: Hebrejský

15. Učitelka: Malý, hebrejský, třeba. Tak, slovesa?

16. Katka: Zabíjeli, umírali.

17. Učitelka: Ano. Ted' jednu větu? Už se podařila někomu? (2) Moni, máś? Myslím, že máš, že?

18. Monika: To není $\mathrm{k}$ tomu.

19. Učitelka: Není to $k$ tomu? Zkus to přečíst, my se podíváme, jestli to je $\mathrm{k}$ tomu, nebo není. Nechceš. (3) Ták, prosím vás, at se nezdržujem, zkuste mně ríct to poslední synonymum.

20.Žáci: (pokrìkuji) Zlo. Koncentrák.

21. Učitelka: Takže zlo, kdo má ještě nějaké slovo?

22. Patrik: Koncentrák.

23. Učitelka: Koncentrák, tak ještě poslední slovo.

24. Žáci: Holokaust.

25. Učitelka: (prikyvuje) Ano.

Hana používá metodu pětilístku s oblibou a často, takže jakmile vysloví její název, žáci již vědí, co se od nich očekává. Reagují přitom $s$ nevolí (viz rádek 2), nebot aktivita je pro ně svým rutinním začleňováním nezáživná a - jak je z pokračování ukázky zřejmé - také nepř́liš př́nosná. $\mathrm{Na}$ zvažování toho, co nového se naučili, není mnoho času, nebot učitelka žáky již po několika málo vteřinách vyzývá, aby sdělili, co si 
zapsali, a stejně tak je ke konci urguje, at se nezdržují (řádky 3 a 18). At už z důvodů nezájmu, či nedostatku času přicházejí ze strany žáků spíše triviální odpovědi (krutý, strašný, zabíjeli, umírali). Rozdíl mezi jejich vědomostmi při vstupu do tématu a při jeho ukončování není z jejich odpovědí nikterak patrný. Celá aktivita se nese v rychlém tempu a prripomíná spíše jakýsi brainstorming.

Pro kvazi-reflexi je tedy charakteristické, že: a) neusiluje o vymezení toho, co nového si žáci z hodiny odnášejí a jak tím navazují na svou předcházející znalostní základnu, b) obsah, s nímž přicházejí žáci, je v důsledku toho banální. Kvazi-reflexe tak neslouží ani jako reflexe, ani jako shrnutí - $\mathrm{k}$ němuž by pro změnu bylo nutné žákovské postřehy provázat zpětnou vazbou učitele.

\subsubsection{Digrese do osobního života žáků aneb A co vy?}

Tento typ bezúčelných pasáží je iniciován tím, že učitel položi žákủm otázku týkající se jejich osobního života. Tato otázka obvykle volně souvisí s probíranou látkou a lze si představit její účelné využití v př́ípadě, že by prezentované žákovské zkušenosti posloužily $\mathrm{k}$ přemostění mezi školní látkou a mimoškolním životem žáků. Mnohdy však toto sdílení osobních informací vytvoří jakousi bezúčelnou odbočku, od níž se potom učitel střihem vrací k původní tematické lince. Hovoříme-li o odbočce, máme na mysli, že celá interakce nijak nepřispívá $\mathrm{k}$ hlubšímu promýšlení tématu, budování nových znalostí či k funkčnímu provázání učiva s každodenním životem žáků:

\section{Ukázka 4:}

$V$ hodině literatury učitelka Hana predétítá se žáky úryvky z knihy „(Ne)obyčejný kluk" o životè chlapce s vrozeným postiženim obličeje. Hana žákưm oznamuje, že název knihy znamená, že hlavní hrdina je v něčem výjimečný a v něcem naopak obyčejný. Nato se rozviji následujici interakce.

1. Učitelka: Myslíte si vy sami, že jste něčím výjimeční? Někdo?

2. Aleš: To každý.

3. Učitelka: Každý je výjimečný?

4. Aleš: No.

5. Učitelka: A když to tak hezky řekls, Aleši, v čem si myslíš, že ty jsi výjimečný?

6. Žáci: (smich)

7. Učitelka: Ale nesmějte se mu, každý si něco najde. Každý je v něčem výjimečný, to je pravda. $\mathrm{V}$ čem si myslišs, že bys vynikal (na Aleše) oproti ostatním? Ty mu tady nenapovídej (na souseda $v$ lavici). $V$ čem si myslís, že bys vynikal? (6)

8. Aleš: $(m l c ̌ r i)$

9. Učitelka: Ted' tě nic nenapadá. (4)

10. Aleš: (kroutí hlavou)

11. Učitelka: Napadá někoho z vás?

12. Žáci: (mluví pres sebe)

13. Učitelka: (vyvolává hlásicího se Honzu) No?

14. Honza: Vynikám v zeměpise.

15. Učitelka: $V$ zeměpise?

16. Honza: Zatím.

17. Učitelka: Řekla bych spíš, že vynikáš $\mathrm{v}$ tom fotbale, třeba.

18. Žáci: (mluví pres sebe)

19. Učitelka: Tak. Přizná se někdo k něčemu, v čem je výjimečný, nebo dobrý? No? 20. Helena: $V$ golfu. 
21. Petr: $\mathrm{V}$ prírodopisu.

22. Učitelka: $V$ golfu, no vidís to. Třeba tam tu paní spisovatelku jednou potkáś, ona taky hraje golf.

23.Zuzka: V plavání.

24. Učitelka: V čem?

25.Zuzka: V plavání.

26. Učitelka: A ted', jak se jmenoval ten hlavní hrdina?

V ukázce 3 vidíme interakci typickou pro tuto kategorii. Žáci podávají mnohačetné odpovědi na osobní otázku. Jejich odpovědi nejsou promyšlené či vyargumentované, žáci pouze identifikují oblasti, v nichž podávají dobré výkony (řádky 14 , $20,21,23)$. Úvodní otázka učitelky přitom dovolovala mnohem širší intepretaci, o čemž svědčí i prvotní odpověd’ Aleše na řádku 2. Následně je však termín „výjimečnost" zúžen na oblast dobrých výsledků v nějaké oblasti. De facto jde o záměnu pojmů výjimečný a vynikající. Jakmile $\mathrm{k}$ tomu dojde (na řádku 21), všechny další žákovské odpovědi už kopírují vytýčený směr. Ten přitom není nikterak užitečný ve vztahu $\mathrm{k}$ intepretaci probíraného literárního díla, $\mathrm{v}$ němž výjimečnost hlavního hrdiny spočivá ve fyzickém handicapu. Interakce pokračuje až do chvíle, kdy ji učitelka ukončí položením zcela nesouvisející otázky na jméno hlavního hrdiny probírané knihy (řádek 26).

$\mathrm{K}$ bezúčelné digresi do osobního života může dojít i tehdy, kdy se aktivizace osobní zkušenosti žáků zdá být velmi relevantní. Například se může zdát být účelné hovořit $\mathrm{v}$ lekci věnované bajkám o tom, jak žáci vnímají různá zvírata a jaké vlastnosti jim připisují. $\mathrm{V}$ hodině učitelky Daniely jsme však mohli sledovat, jak se právě takováto aktivita stala bezúčelnou. $\mathrm{Na}$ začátku hodiny Daniela vyzvala žáky, aby si představili své oblíbené zviŕre. Žáci jmenovali různá zviŕata (křečka, psa, kočku) a jako důvod, proč je vybrali, opakovaně uváděli, že tato zviŕata jsou roztomilá. Následně Daniela požádala žáky, at si představí zvíre, z nějž mají strach. Žáci uváděli pavouky, mravence či žížaly a zdůvodňovali to tím, že tito živočichové vyvolávají znechucení a jsou zákeřní. Po této aktivitě Daniela oznámila, že tématem hodiny je bajka a dále se třída $\mathrm{k}$ proběhlé interakci na téma oblíbených a neoblíbených zviŕat již nevrátila. Jádrem lekce bylo čtení bajky $O$ vlku a beránku, tyto postavy se však v debatě o oblíbených a neoblíbených zvířatech neobjevily, nebylo tedy $\mathrm{k}$ čemu ze žákovské zkušenosti odkazovat.

\subsubsection{Sousedské klábosení}

Jak napovídá samotný název tohoto typu bezúčelných pasáží, pro sousedské klábosení je charakteristické živé zapojení účastníků do interakce, v níž všichni rádoby mají co říct, nebot všichni mohou mít svůj názor. Žáci na sebe reagují navzájem, takže sousedské klábosení může z hlediska své organizace připomínat diskusi. Proč se tedy jedná o bezúčelné situace? Při sousedském klábosení totiž není evidentní jakýkoli cíl, takže není jasné, jaký má být jeho závěr. Tomu nahrává skutečnost, že v tomto typu situací nedochází ke korigování žákovských odpovědí, a to ani tehdy, když jsou zjevně beze smyslu. 


\section{Ukázka 5:}

$V$ hodinè občanské výchovy se učitel Radek šzáky bavi na téma hypoték a exekucí. Žáci shlédnou několik príběbư rodin, které se potýkaly sexekuci a existenčnimi problémy, načež se jich Radek ptá otázkou, která otevirá následujicí ukázku:

1. Učitel: A víte co? (1) Jinak. Najděte tu spojitost jako třída. (3) $\mathrm{V}$ těch příbězích. Najděte jako trrída (.) spojitosti v těch příbězích. (2) Máte volno na to.

2. Elen: Tak ti lidi jsou blbí, no.

3. Žáci: (smich)

4. Učitel: Jsou blbí. (s úsmèvem)

5. Žáci: (šum, prekrìkují se a směji se) (7)

6. Elen: A před svatbou se tě ptají na co?

7. Lucka: No, jestli to víś, ne?

8. Elen: Jestli to víšs, takže to je jeho problém.

9. Lucka:Nevíšs, jestli ví všechno.

10. Iveta: Ale on nevěděl, že ona mu zdrhne, chápeš?

11. Elen: Ale tak to je jedna věc, ale on měl vědět to, že ona má dluhy, když si ju bral.

12. Iveta: Ježǐšs, byl hluchej, nevěděl o tom.

13. Dívky: (smích)

14. Tomáš: Měla jít na psychiatrii.

15. Iveta: Ale asi na to nemá penízeeee.

16. Karel: Podle mě je závislá.

17. Iveta: Ježiiiiiš.

18. Žáci: (překrikuji se) (5)

19. Tomáš: To máš jak s fetákem. Myslíš, že feták, když má hlad, tak že si koupí rohlík, jo?

20.Žáci: $($ šum $)(2)$

21. (...)

22. Iveta: $V y$ jste hrozně bezohlední všichni.

23. Karel: Jak bezohlední?

24. Śárka: Hlavně ty.
25. Dívky: (smích) (2)

26. Tomáš: Každej sám za sebe.

27. Elen: Ale člověk si za to může sám, že se dostane do takovýho problému.

28. Šárka: Já nic neřikám.

29. Učitel: Ted'ka, ehm, ted' si sedněte prosím na místa, (1) sedněte si na místa. (20) Napište si, prosím, (2) tak. (2) Jo. Co měly společného, ehm, ty př́běhy teda? (.) Pište si to ted'ka, prosím, to, co měli společného, dáme to dohromady. Tak dluhy, to je to první.

Ukázka je uvedena zadáním učitele, který žáky vyzývá, aby $\mathrm{v}$ rámci tř́ př́běhů rodin, které se potýkaly s exekucí, našli spojitosti (řádek 1). Jedná se tedy o otevřenou otázku vyšší kognitivní náročnosti, která by mohla stimulovat skutečný dialog mezi žáky. Ke společným charakteristikám všech př́běhů se vztahuje odpověd' žákyně Elen (řádek 2), byt' o kognitivní korespondenci s otázkou již lze pochybovat. Následující žákovské příspěvky se od zadání zcela odklánějí a žáci se namísto hledání styčných ploch vyjadřují k osudům a hodnocení jednotlivých postav př́běhů (řádky 10-16). Jejich repliky přitom postrádají jakoukoli elaboraci, argumentaci a mnohdy také spojitost. Učitel však do jejich výměny nijak nevstupuje, aby žáky k zadání vrátil, a proto se záhy původní téma ztratí úplně a žáci plynule přecházejí na hodnocení svých spolužáků a jejich bezohlednosti (rádky 21-27). Teprve v tuto chvíli se do interakce vrací učitel, který s předcházejícími žákovskými replikami vůbec nepracuje, a namísto toho svou původní otázku zodpovídá sám. 
Pro sousedské klábosení je tedy typické, že: a) učitel se pokouší iniciovat dialog, avšak žáci nepřispívají kompetentně, a tak dialog postupně degeneruje; b) aktivita záhy ztrácí svůj cíl a proměňuje se v bezbřehé klábosení o tom, co si kdo ze žáků myslí. Klíčový faktor toho, že se aktivita promění $\mathrm{v}$ neúčelnou, spočívá $\mathrm{v}$ jejím nedostatečném korigování ze strany učitele, která nenastaví, př́padně neuhlídá standard validního žákovského př́spěvku. V uvedené ukázce se např́klad učitel Radek jakýchkoli zásahů do žákovského dialogu vzdal.

\subsubsection{Mimo dosah žáků}

Také v těchto situacích učitel volí otevřené zadání, často vyšší kognitivní náročnosti. Na rozdíl od sousedského klábosení se prritom $\mathrm{z}$ interakce nestahuje - hlídá zadání a zpravidla má přesnou představu o tom, kam by celá aktivita mohla vést. Situace však přesto vyznívá bezúčelně. Důvodem je v tomto př́padě nevhodně nastavené zadání - učitel se žáků ptá na jejich stanovisko tam, kde ještě nejsou schopni situaci vyhodnotit, nebot' se nachází mimo jejich zkušenost i představivost. Žákovské prríspěvky jsou $\mathrm{v}$ důsledku neproduktivní a učitel to svými vstupy nemůže zvrátit.

\section{Ukázka 6:}

Ucitel Jonás se v rámci výuky literatury, $v$ hodinè na téma Romeo a Julie žáků ptá, kdo by z perspektivy jejich rodiču byl vnimán jako nevyhovujici partner:

1. Učitel: Nebo dovedete si představit, že třeba byste si nemohli domů přivíst třeba nějakýho partnera, př́tele, prítelkyni (2), že by se to vašim rodičům nelíbilo? (15) Dane, mohl by sis třeba domů jako partnera privíist kluka? (hlasitý smich všech) (4)

2. Dan: Já mám dost dneska. (3) Co já vím. Já nechcu kluky. (smich všech)

3. Učitel: $\mathrm{V}$ pořádku, já třeba vím, že když bych si domů přived partnera, jakože mužského pohlaví, tak tatínkovi by se to asi úplně nelíbilo, byl by z toho smutný. (2) Maminka, ta by nic neřekla, ale hrála by, že je hrozně ráda, že jsem si přece jenom někoho našel (1) a že jdu za svým štěstím. Když bych si přived slečnu, která by hodně pila alkohol, (1) tak bych měl velice dlouhou rozmluvu (1) a vim, že by se to mým rodičům nelíbilo vủbec. Ted' se ptám vás (2), koho vy byste si nesměli přivést domů. (žáci se směji) (6) Kdo z vás ví, koho by si nemohl dovést domů? (2) Adame, kdo by to byl, prosím tě? (učitel se zvedá ze židle a stojí u okna)

4. Učitel: Co Aneta?

5. Aneta: No, asi někoho, kdo je třeba na drogách.

6. Učitel: Ehe (2). Má někdo podobné rodiče jako Aneta? (2) Že byste si nemohli domů přivést nějakýho fetáka?

7. Simona: Já nevím. Já si nemůžu přivést nikoho.

8. (všichni zvedaji ruce krom Simony a Dominika; šum ve trídè) (6)

9. Dita: Fetáka.

10. Nikol: No, no třeba nějakýho šílence.

Učitel se snaží od žáků získat spektrum odpovědí, aby se poté mohl dále ptát, jak by rodiče $\mathrm{v}$ daném př́padě reagovali a jak by se je žáci snažili přesvědčit, aby partnera přijali. Již na první otázce (kdo je nevyhovující 
partner) však aktivita začíná ztroskotávat. Žákovské odpovědi jsou poměrně plytké a nejisté, přestože učitel se snaží žáky aktivizovat a sám jde s kủží na trh (viz rádek 3).

Analogickou podobu mají všechny situace, $v$ nichž učitelé zvolí zadání, $\mathrm{k}$ němuž se žáci nemohou (a př́padně nechtějí) relevantně vyjádřit. Když učitel Marek žáky vede $\mathrm{k}$ tomu, at si představí, že jsou maturanti, a hovoří o tom, jakou podobu by měla mít maturitní zkouška, když učitel Radek po žácích požaduje, at si zkusí simulovat jednání o zbylé peníze ve státním rozpočtu, případně když učitelka Martina vybízí žáky, at se rozhodují o amnestii, vyznívají tyto pasáže do prázdna, nebot žákovské odpovědi jsou inhibovány jejich znalostmi a zkušenostmi. Dodejme, že nikoli všechny výukové situace, které se nacházejí mimo dosah žáků, nutně musejí být bezúčelné. Pokud dochází $\mathrm{k}$ překročení žákovské aktuální úrovně vývoje a žáci se nacházejí v zóně nejbližšího vývoje, může dojít $\mathrm{k}$ vyučování, které předchází vývoj a optimálně mu napomáhá (Vygotsky, 1978). V bezúčelných pasážích mimo dosah žáků však $\mathrm{k}$ tomuto procesu nedochází - at́ již proto, že zadání se nachází daleko za zónou nejbližšího vývoje, nebo kvůli nedostatečnému vedení ze strany učitele.

Interakce, které jsou otevřeny zadáním mimo dosah žáků, také $\mathrm{v}$ důsledku svého vývoje postrádají návaznost na téma hodiny. Učitel totiž ve svém plánu počítá $s$ bohatším žákovským přispěním, o něž se bude moci oprít a $\mathrm{k}$ tématu je vztáhnout. Učitel Jonáš si např́iklad představoval, že bude možnosti řešení svých žáků konfrontovat $s$ možnostmi, které měli Romeo a Julie, což bylo tématem vyučovací hodiny.

\subsubsection{Co je vlastní bezúčelným pasážím}

Popsali jsme, že v rámci bezúčelných pasáží můžeme identifikovat pět různých kategorií. Podívejme se nyní, jaké mají společné charakteristiky a co je odlišuje. Prvním společným jmenovatelem je jejich záměrné použití ve výuce. Ani $\mathrm{v}$ jednom př́padě se nejedná o spontánní aktivitu, která by ve výuce vykrystalizovala znenadání. At́ už se jedná o hádání tématu hodiny, nebo sousedské klábosení, učitelé tyto aktivity do výuky zařazují záměrně, ve shodě se svým předchozím plánem.

Důvodem, který k tomu učitele vede, je dle našeho názoru snaha o vyšší žákovskou participaci, což lze vyhodnotit jakou druhou společnou charakteristiku bezúčelných pasáží. Zastoupení žákovských replik totiž naprríč jednotlivými typy bezúčelných pasáží stoupá. Výjimku tvoří pouze kategorie mimo dosah žáků. $\mathrm{V}$ té zastoupení žákovských replik neroste a je oproti ostatním výrazně nižší, nebot žáci nevědí, jak na zadání reagovat, př́ípadně na ně reagovat nemohou či nechtějí. V ostatních kategoriích lze sledovat bohatou žákovskou participaci. Zdůrazněme však, že se jedná o žákovské repliky bez př́tomnosti argumentace (viz diskuse v kapitole 5), což dokládají také všechny ukázky v tomto textu.

$\mathrm{O}$ všech kategoriích víme, že je lze vyhodnotit jako bezúčelné. Jaká je tedy návaznost na téma hodiny a její cíle? Nejbliže tématu hodiny má kategorie sousedské klábosení, na jejímž počátku je evidentní spojitost $s$ tématem (samot- 
né otázky, které toto klábosení otevírají, stejně jako několik prvních reakcí žáků, lze mnohdy považovat za účelné). Návaznost na téma se zde ztrácí až v průběhu aktivity $\mathrm{v}$ důsledku jejího nedostatečného řízení ze strany učitele. Jinak je tomu $\mathrm{v}$ kategoriích kvazi-evokace, osobní život či nevhodné zadání, kde je návaznost na téma hodiny od počátku pouze asociativní. $V$ rámci hádání tématu se návaznost na téma hodiny vynořuje na samotném konci aktivity, nebot́ jeho „objevení" tvoří její podstatu. K naplnění výukových cílů zde však nedochází. Zdá se, že učitelé v těchto aktivitách cíleně odbočují od témat hodiny a výukových cílů (v př́ípadě sousedského klábosení na ně spíše rezignují) za cenu toho, že nechají žáky chvíli hovořit. Tento nález je ve shodě $s$ našimi předchozími výsledky o tom, že učitelé chtějí s žáky diskutovat, ale vnímají to jako zdržení od svého výukového plánu (Šed’ová, Švaříček \& Šalamounová, 2012), nebot žákovskou diskusi nejsou schopni navigovat účelným směrem. Žáci tedy v těchto pasážích výrazně participují - s ohlédnutím od účelnosti by bylo možné říct, že učitelé jsou velmi úspěšní ve své snaze žáky aktivizovat. Jedná se však o bezúčelnou participaci, nebot učebníaktivity žákům nejsou nikterak propojeny s odborným oborovým jednáním, myšlením či jazykem oboru.

Všechny typy bezúčelných pasáží dokládají, že pokud má dialogické vyučování dostát krom svých formálních znaků také principu účelnosti, klade vysoké nároky na učitele. Učitel musí disponovat značnou oborovou výbavou - musí mít široké faktické a konceptuální znalosti oboru, aby byl schopen adekvátně reagovat na výroky žáků. Učitel Marek z tohoto hlediska selhal $\mathrm{v}$ rámci hádání tématu, učitel Radek při sousedském klábosení. Současně musí mít učitel rozvinuté oborově didaktické znalosti - musí dokázat přiměřeně odhadnout aktuální zkušenosti, znalosti a motivace žáků ve vztahu ke konkrétnímu tématu, aby předešel např́klad pasážím mimo dosah žáků.

Zamysleme se ještě nad tím, zda jsou bezúčelné pasáže tvořeny aktivitami, které jsou svou povahou předurčeny $\mathrm{k}$ tomu, aby byly bezúčelné, nebo by bylo možné je revidovat. Domníváme se, že vyjma kategorie hádání tématu je možné, aby prezentované aktivity nabyly účelnosti a měly ve výuce své opodstatnění, pokud by učitelé více promysleli, jak je navázat na téma a cíle hodiny a aktivity stále „kormidlovali“ požadovaným směrem. Na zřeteli by tedy neměli pouze to, zda budou žáci participovat, ale také $\mathrm{k}$ čemu mají jejich prŕspěvky vést. Pokud by např́íklad žáci místo přesunu k sousedskému klábosení zůstali u tématu hodiny a byli učitelem vedeni ke zdůvodňování svých stanovisek, jednalo by se bezesporu o účelnou aktivitu. Stejně tak kvazi-evokace či kvazi-reflexe se při zvážení smyslu jejich využití mohou stát vysoce hodnotnou metodou. Jedinou výjimku tvoří (učiteli oblíbená) kategorie hádání tématu, kterou není možné revidovat tak, aby se změnil její ústřední rys v podobě žákovského hádání. 


\subsection{Kde se berou bezúčelné pasáže}

Uvedli jsme, že existenci bezúčelných pasáží $\mathrm{v}$ našem datovém materiálu lze připsat snaze učitele realizovat dialogické vyučování. Podporu pro toto tvrzení poskytují data $\mathrm{z}$ reflektivních rozhovorů stimulovaných videonahrávkami. Analýza těch částí rozhovorů, $\mathrm{v}$ nichž se hovoří o bezúčelných pasážích, odhaluje dvě možné prŕíciny jejich vzniku: 1 . automatické převzetí výukové metody, u níž nedošlo k promyšlení jejího cíle; 2 . nečekaný vývoj interakce ve výuce.

První př́pad dokumentuje ukázka 7 , v níž výzkumnice hovoří s učitelkou Hanou o situaci, která byla zachycena v ukázce 3. $\mathrm{V}$ dané hodině byla předčítána kniha popisující holocaust očima dítěte. V rámci výkladu Hana představila žákům slovo šoa coby hebrejský výraz pro holocaust. Následně je vyzvala, aby si do sešitů vytvořili pětilístek - grafické schéma, v němž žáci pěti různými způsoby $s$ použitím přesně daného počtu slov (jedno až čtyři) a přesně daných slovních druhů (podstatná jména, př́idavná jména, slovesa) zaznamenávají námět textu. Hana žákům zadala, že první slovo pětilístku má být šoa, zbytek měl vyplnit každý po svém. Někteř́ žáci volili slova vystihující věcnou podstatu holocaustu (např. krutý, zabíjeli, zlo), jiní se snažili vystihnout charakter slova šoa (např. hebrejský, starý). Poté žáci výsledky své práce četli ostatním. V navazujícím rozhovoru se výzkumnice dotazovala na cíl aktivity $s$ pětilístkem.

\section{Ukázka 7:}

Rozhovor mezi výzkumnici a učitelkou Hanou po hodiné literatury vènované knize s tematikou holokaustu.

1. Výzkumnice: K čemu je dobrej ten pětilístek, se ještě zeptám?

2. Hana: Takový shrnutí jako jenom. Vyloženě takový shrnutí, aby si to utvrdili, potvrdili ty pojmy.

3. Výzkumnice: A nevadí vám teda, že oni si tam napíšou každej něco jinýho úplně? Že nemáte vủbec kontrolu nad tím, co tam mají?

4. Hana: $\mathrm{Ne}$, to mi nevadí.

5. Výzkumnice: $\check{Z}$ e tady třeba (.)

6. Hana: Že jako kdybych měla všechny přečíst, jestli to mají dobře?

7. Výzkumnice: Ne, já se spíš na to ptám jako, když řeknete jako shrnutí, ted' oni si tam napíšou každej něco jinýho, ted' si tam napíśou Šoa a někdo napsal př́idavná jména krutý a strašný a někdo jiný napsal př́idavná jména starý a hebrejský, tak oni ve skutečnosti píšou o úplně různých jako dimenzích toho jevu.

8. Hana: To jo, ale jsou pořád, jsou tam pořád. Jakoby.

9. Výzkumnice: No tak to jako jo.

10. Hana: No, tak to už potom je jedno. To je jako když si vezmete škola, tak každej si tam, žejo, napiše, někdo napiše, že je velká, že je to budova. A někdo napíše, já nevím, že se tam musí učit, jo? Nebo každý to bere z jinýho pohledu jakoby.

11.Výzkumnice: Jasně. A to vám teda jako nepřijde (.) nějak jako že by vám to komplikovalo práci, že by tam každý měli napsaný něco jinýho?

12. Hana: $\mathrm{Ne}$, to mě tak jako (.) At' si tam napíšou, co chtějí. 
13. Výzkumnice: A pracujete $s$ tím potom ještě nějak?

14. Hana: Ne. Takhle jako vždycky tak se udělá ten pětilístek. Tak se projede jakoby. 15. Výzkumnice: Jo, protože když on tady ten, to byl myslím ten Petr, řekl př́idavná jména starý, hebrejský, tak ony se ve skutečnosti nevztahují $\mathrm{k}$ vlastnostem holocaustu, že jo. Nebo (.)

16. Hana: Tak ale do té velké problematiky to nějak zapadá (smich).

17. Výzkumnice: Jo, protože on popisuje vlastnosti toho slova, jako kdyby lingvistický vlastně. Ale je to zas jako někde úplně jinde než předtím, vlastně.

18. Hana: Jo, takhle jako že tito, ten vyloženě teda zkoumá to slovo a ti druzí berou to období jako, tu situaci.

19.Výzkumnice: Jo, a pak se vlastně vždycky řekne (.) jak vy máte takový ty celkem lakonický zpětný vazby, což ale mají skoro všichni učitelé, jo? Tak se řekne jojojo, krutý, strašný, jojojo, starý, hebrejský. A vlastně se to vůbec nekomentuje.

20. Hana: To já kdybych měla každýmu, to já bych na to potřebovala půl DNE!

21. Výzkumnice: Jasně.

22. Hana: To by nešlo.

23. Výzkumnice: To máte pravdu.

24. Hana: To by nešlo prostě. Už takhle to nestíhám.

Z ukázky 7 je zjevné, že Hanina představa o tom, jaký je cíl zařazené aktivity, je velmi nekonkrétní (viz řádky 2, 16). Pětilístek přitom zařazuje do svých hodin často, považuje jej za prospěšný, avšak není $s$ to přesně vysvětlit, $v$ čem jeho užitečnost spočívá. $S$ touto metodou se seznámila prostřednictvím samostudia na internetu (přesný zdroj v rozhovoru neuvedla). Z toho, jak v rozhovoru vypovídá, se zdá, že cíl není v tom, co si žáci zapíšou (viz řádky $4,10,12$ ), ani v tom, sledovat jejich myšlenkové procesy (viz řádky 20, 22). Smysl aktivity je patrně $\mathrm{v}$ činnosti samé - viz shrnutí na řádku 14 , jde o to udélat pětilístek. Ten Hana vnímá jako progresivní metodu, jež žáky aktivizuje, nebot’ sami dělají zápis a pak jej sdělují ostatním. Podle Hany je tudíž v souladu s konceptem dialogického vyučování.

Princip bezúčelného přebírání výukových metod se $\mathrm{v}$ našem datovém materiálu objevil ve dvojí podobě. Jednak šlo o výsledek přechozího sebevzdělávání učitelů, kteř́ čerpali z metodických materiálů pro učitele (např́klad z webu rvp.cz či www. kritickemysleni.cz) nebo ze seminářů profesního vzdělávání, jichž se $\mathrm{v}$ minulosti účastnili. Pozorovat jsme tento fenomén mohli však také prrímo $\mathrm{v}$ reálném čase, nebot' sami jsme na workshopech prezentovali učitelům různé potenciálně použitelné postupy vhodné pro použití v dialogickém vyučování a následně jsme se někdy setkávali s jejich bezúčelným použitím.

Druhou př́činou vzniku bezúčelných pasáží je nečekaný vývoj interakce ve výuce oproti tomu, co si od ní sliboval učitel. $\mathrm{V}$ tomto př́ípadě učitel pečlivě plánuje nejen to, jaké bude zadání aktivity, ale také $\mathrm{k}$ čemu má přesně vést. $\mathrm{V}$ reálu pak ovšem dojde $\mathrm{k}$ tomu, že se žáci zachovají jinak, než učitel předpokládal, a připravený plán se učiteli nepodaří flexibilně uzpůsobit vyústění žákovské interakce. $\mathrm{K}$ takovému vývoji došlo např́klad $\mathrm{v}$ hodině učitelky 
Daniely věnované bajkám. Situaci jsme popsali v kapitole 4.1.3. Žáci hovořili o svých oblíbených a neoblíbených zviŕatech, avšak tento rozhovor byl pouhou digresí, nikoli východiskem pro další výklad či práci žáků. V reflektivním rozhovoru vyšlo najevo, že se Daniela domnívala, že se úvodní aktivita tematizující oblíbená a neoblíbená zviŕata propojí s jinou aktivitou zařazenou $\mathrm{v}$ pozdější části hodiny, $\mathrm{v}$ níž se učitelka ptala na typická zviŕata vystupující v bajkách a schematické vlastnosti, které jsou jim v bajkách prripisovány.

\section{Ukázka 8:}

Rozhovor mezi výzkumnici a učitelkou Danielou po hodinè literatury vènované bajkám.

1. Výzkumnice: Takže ted' je tam ta část, kde vyjmenovávají zviŕata, co vystupují v bajkách. Tak jak to funguje? Vlastně na začátku byla ta evokace, kdo jaký má rád a kdo se jakýho bojí...

2. Daniela: Hm. Mohlo to být lepší, protože tam už nezaznělo nic $\mathrm{z}$ toho, co oni říkali na začátku. Vlastně, že jako by se to muselo spojit víc ještě $s$ tou roztomilostí. Jo, jak tam ř́kali, že je nějaký zvíře roztomilý, nebo že se bojí toho hmyzu, tak klidně jsem to tam mohla víc otevrít (.) Jako že v těch bajkách (.), že oni ř́kali hmyz, že se ho bojí, pavouků, že se ho bojí (.), ale takhle v bajkách hmyz většinou nevystupuje. Tak se zeptat, kdo teda vystupuje jako ten, koho se bojíte, nebo... (2) Prostě asi víc to spojit, protože nevím, jestli tady to nebylo až tak úplně, nebylo to tak pěkně uzavřený, že jsem na to reagovala málo, že pak vlastně ta evokace na začátku, pokud oni říkali nějakou kočičku a pavouka, tak se mně tady vůbec nespojilo $s$ beránkem a vlkem. Takže víc jako (.) No, prostě navázat to líp by to chtělo, aby to bylo jasný. 3. Výzkumnice: Jo, aby (.) jakože smyslu té aktivity rozumím. A tys asi myslela, že padnou jiný zviŕăata tam na začátku, ne?

4. Daniela: No, jasně. A když už nepadly, když tam nebyla ani žádná (.) Myslela jsem třeba nějaká ta šelma...

Z ukázky je zjevné, že Daniela hodinu plánovala do té míry, že předjímala možné žákovské odpovědi na otázku po oblíbených a neoblíbených zvíratech. Sama je $s$ to reflektovat, že nedošlo $\mathrm{k}$ zamýšlenému propojení, a to proto, že žáci uváděli takové vlastnosti, jejichž nositeli daná zvírata v bajkách nejsou (viz řádek 2). Ani v průběhu rozhovoru nenalézá řešení dané situace, nebot původní otázka je př́liš otevřená a teprve průběh interakce ve výuce ukázal, že to, jak dnešní děti vnímají zvírata, je poměrně vzdálené od tradiční ikonografie bajek.

\section{3 Účelnost ohrožena dialogem?}

V předchozích kapitolách jsme popsali různé typy bezúčelných pasáží a rozkryli jejich zdroje. Zjednodušeně lze říci, že cesta do pekel může být dlážděna dobrými úmysly, nebot bezúčelnost je $\mathrm{v}$ našem materiálu zjevně důsledkem snahy o zavádění dialogického vyučování, obecněji snahy o progresivní pedagogiku a ještě obecněji snahy učitelů o vlastní profesní rozvoj. Platí tedy, že snaha ustavit dialog $s$ jeho formálními znaky ohrožuje účelnost výuky? 
Pokud naše data prozkoumáme systematicky za pomoci jednoduchých kvantitativních procedur, zjistíme, že tento skeptický pohled není namístě. Porovnáme-li epizody, které byly natočeny $\mathrm{v}$ hodinách před zahájením intervenčního programu, a epizody z posledních dvou lekcí, zjistíme, že účelnost $v$ důsledku snahy o zavedení dialogického vyučování nepoklesla. Před programem bylo účelně využito $44 \%$ výukového času, na jeho konci potom $54 \%$. Vidíme tedy zřetelný nárůst účelnosti.

Jako klíčový indikátor dialogického vyučování jsme identifikovali množství žákovských promluv s argumentací. Pokud tuto proměnnou korelujeme napříc všemi natočenými epizodami s množstvím účelného času v jednotlivých epizodách, dostaneme Pearsonův korelační koeficient o hodnotě $0,39(\mathrm{p}=0,05)$. Jinými slovy, $\mathrm{v}$ účelných epizodách se vyskytuje výrazně více vyargumentovaných žákovských promluv. Klíčový indikátor a princip sledovaný v této studii jsou v souladu, vzájemně se podporují.

Dostáváme se tedy ke dvěma protichůdným nálezům. Na jedné straně kvalitativní analýza ukazuje existenci bezúčelných pasáží, které lze připsat snaze učitelů o zavedení dialogického vyučování a navýšení žákovské participace. Na druhé straně kvantitativní analýza svědčí o tom, že čím více výuka naplňuje klíčový indikátor dialogického vyučování, tím je bezúčelných pasáží méně. Domníváme se, že tento zdánlivý paradox má své řešení. Bezúčelné pasáže jsou v zásadě výsledkem nezvládnutého použití dialogických metod. Ačkoli je učitelé do hodin zasazují se záměrem dosáhnout dialogických indikátorů, reálně $\mathrm{k}$ tomu nedochází. Ani jedna $\mathrm{z}$ ukázek $\mathrm{z}$ výuky prezentovaných $\mathrm{v}$ této studii není složena $\mathrm{z}$ příkladů rozvité žákovské argumentace (a také $\mathrm{v}$ datech $\mathrm{z}$ ostatních bezúčelných pasáží se lze $s$ žákovskou argumentací setkat zcela sporadicky, ta navíc vznikla v podstatě náhodou). Výše uvedená korelace dokazuje, že nejde o náhodu danou subjektivním výběrem ukázek, nýbrž o zřetelný vzorec $v$ datech. Platí tedy, že se žáci chovají dialogicky spíše v účelných pasážích než $\mathrm{v}$ neúčelných. Tento nález se zdá být nelogický. Proč by si žáci měli lámat hlavu tím, že daná interakce nenaplňuje kurikulární cíle?

Domníváme se, že je to sám učitel, kdo svým chováním tento efekt mediuje. Naše předcházející analýzy ukázaly (viz Šed’ová et al., 2014, 2016a, 2016b), že promluvy $s$ argumentem jsou predikovány tím, že učitel klade žákům určitý typ otázek a rozpracovává jejich odpovědi navazujícími otázkami. Učitelé to ovšem nedělají vždy, ale patrně jen $\mathrm{v}$ prrípadech, kdy mají pocit (intuitivní, nebot $\mathrm{v}$ dané chvíli nejsou s to probíhající dění racionálně analyzovat), že se interakce rozvíjí slibným směrem. Pokud nedostávají ze třídy repliky, které považují za potenciálně slibné, nepracují na jejich elaboraci a prohlubování, nýbrž spíše vyčkávají, jak se interakce vyvine a zda se přiblíží jejich záměrům (v důsledku se mohou řízení interakce také zcela vzdát a pouze vyčkávat). Toto vysvětlení dobře odpovídá např́íklad interakci reflektované v ukázce 4 či 8 . Aktivita sice proběhne, ale učitel do ní neinvestuje čas, který by vyžadovalo povzbuzování žáků $\mathrm{k}$ rozvitějším 
odpovědím. Tato interpretace koresponduje $s$ tím, jak se o věci vyjadřuje učitelka Daniela v ukázce 7. Jinými slovy: ve snaze dosáhnout indikátorů dialogického vyučování učitelé nasazují určité výukové metody (at' už převzaté, nebo autorsky vytvořené). Ty však začnou jako dialogické fungovat až tehdy, když se podaří paralelně naplnit také princip účelnosti.

\section{DiSKUSE A ZÁVĚR}

Tuto studii jsme otevřeli otázkou, zda v dialogickém vyučování nedochází $\mathrm{k}$ vyprazdňování obsahu výuky. Všimli jsme si totiž, že při zavádění dialogického vyučování dochází u učitelů k porušování principu účelnosti. Abychom na položenou otázku získali odpověd', podrobili jsme naše data $\mathrm{z}$ intervenčního projektu systematické analýze. Jejím prostřednictvím jsme objevili řadu bezúčelných pasáží, tedy dlouhých kompaktních úsekủ výuky, které se zcela odklánějí od výukového cíle učitele i od nadřazených předmětových cílů. Identifikovali jsme celkem pět kategorií interaktivních bezúčelných pasáží. Jakkoli se od sebe jednotlivé typy liší, sdílejí společnou vlastnost, a tou je nespojitost mezi tematickou a konceptovou vrstvou učiva (viz Slavík et al., 2014). Disciplinární koncepty a činnosti zůstávají nenapojeny na žákovské zkušenosti, a to přesto, že jsou tyto zkušenosti aktivovány a vtaženy do komunikace ve shodě $s$ cíli obou sledovaných předmětů. Bezúčelné pasáže typu kvazi-evokací a kvazi-reflexí, digresí do osobního života či sousedského klábosení jsou postaveny tom, že žáci sdílejí vlastní zkušenosti či momentální nápady. Nedojde však k tomu, že by žákovské príi- spěvky byly spojeny s konceptuální vrstvou, $s$ koncepty př́islušného vědního oboru včetně specifických činností. V terminologii Janíka et al. (2013) se jedná o utajené poznávání. Žáci živě participují, avšak spojitost mezi aktivitami, které ve výuce probíhají, a učivem zůstává skrytá.

Jiný typ nepropojení nastává $\mathrm{v}$ príípadě bezúčelných hádanek a zadání mimo dosah žáků. Zde učitel vybízí $\mathrm{k}$ aktivaci takových znalostí či zkušeností, jimiž žáci nedisponují, př́padně je nechtějí sdílet. $V$ důsledku tedy dochází $\mathrm{k}$ tomu, že žáci na výuce participují, ale jejich příspěvky z velké míry nemají (a ze své podstaty ani mít nemohou) valnou hodnotu. $\mathrm{V}$ tomto prípadě jde o specifický typ formalismu, který neodpovídá ani utajenému poznávání, ani poznávání odcizenému (srov. Janík et al., 2013). Tento formalismus můžeme označit jako neadekvátní poznávání. Učitel v těchto prrípadech požaduje po žácích informace, které jsou pro ně nepřiměrené a o kterých nemohou relevantně hovořit. $\mathrm{V}$ těchto situacích by tedy bylo účelnějšs žźákům informaci jednoduše sdělit, nebot' oni sami ji nejsou s to konstruovat.

V teorii dialogického vyučování není prosazována představa, že by mělo docházet k exkluzivnímu uplatňování dialogu v průběhu celé výuky. Naopak, učitel má disponovat širokým repertoárem komunikačních vzorců včetně autoritativních (Reznitskaya \& Wilkinson, 2015). Někteří autoři (Scott, 2008; Nurkka et al., 2014) hovoří o rytmizaci výukové komunikace, kdy dochází $\mathrm{k}$ přepínání mezi fázemi prezentování informací učitelem (autoritativní př́stup) a kolaborativního zkoumání různorodých myšlenek a konceptů (dialogický př́stup). Neadekvátní poznávaní 
tak lze chápat jako deficit $\mathrm{v}$ rytmizaci výukové komunikace, kdy učitel ve vhodnou chvíli nepřejde z rytmu kolaborativního zkoumání $\mathrm{k}$ autoritativnímu prístupu.

$\mathrm{Z}$ našich nálezů dále vyplynulo, že bezúčelné pasáže vznikají dvojím způsobem. Jednak v důsledku nečekaného vývoje oproti plánu, který měl učitel pro výuku připravený, jednak v důsledku nezacíleného, nedostatečně promyšleného převzetí výukové metody. Co se týče nečekaného vývoje oproti původnímu plánu, jde patrně o riziko, které je s dialogickým vyučováním těsně spjato. Twiner et al. (2014) upozorňují, že při dialogickém vyučování dochází $\mathrm{k}$ přepínání mezi dvěma trajektoriemi - zamýšlenou, tedy takovou, která je založena na aktivitách a materiálech předem přichystaných učitelem, a okamžitou, tedy takovou, která vzniká prímo ve výuce v důsledku nepředvídaných komunikačních aktivit žáků. Twiner et al. (2014) chápou okamžité trajektorie jako velmi významné a ukazují, jakým způsobem mohou podporovat a prohlubovat porozumění žákủ. Právě okamžité trajektorie nicméně ze své podstaty znamenají odbočení od plánu hodiny, přičemž učitel nemůže na jejich počátku zcela odhadnout, kam budou směrovat a jaká bude jejich souvislost $s$ připravenými cíli výuky. Produktivně vystavět okamžitou trajektorii je - jak dokládají naše nálezy - velmi obtížné.

Jako další důvod porušení účelnosti jsme identifikovali nezacílené prevevzetí výukové metody, tzn. převzetí metody bez promyšlení jejího smyslu a cíle. Tento fenomén si podle nás zasluhuje soustředěnou pozornost, nebot má patrně obecnější platnost a není omezen na situaci, kdy jsou implementovány postupy dialogického vyučování. $V$ tomto prípadě se učitelé pouštějí do aplikace metody, která je jim z nějakého důvodu sympatická, aniž by důsledně reflektovali její účel, cíle, kterých lze jejím prostřednictvím dosáhnout, a vhodnost jejího použití v zamýšleném kontextu. Metoda se jim zkrátka líbí, což jim k jejímu převzetí stačí. De Vries, Jansen \& van de Gift (2013) uvádějí, že nejběžnějším typem dalš́ho vzdělávání učitelů je aktualizace didaktických dovedností prostřednictvím studia odborné literatury a účasti na metodických školeních, naopak nejméně četná je reflexe vlastní praxe. Toto tvrzení dobře rezonuje $s$ našimi daty, nebot řada metod, které jsme identifikovali $\mathrm{v}$ našem datovém materiálu, byla převzatá $\mathrm{z}$ metodických materiálů pro učitele (např́klad z webu rvp.cz či www.kritickemysleni.cz) nebo se s nimi učitelé setkali na seminárích profesního vzdělávání. $V$ této studii nicméně ukazujeme limity tohoto rozširreného př́stupu $\mathrm{k}$ učitelskému vzdělávání, který je ve své podstatě imitativní - založený na tom, že se učitelé snaží napodobit metodu úspěšně vyzkoušenou a doporučenou jiným učitelem. Jak uvádějí Lefstein \& Snell (2014), metoda, která funguje $\mathrm{v}$ jednom kontextu, nemusí stejným způsobem fungovat $\mathrm{v}$ jiném kontextu. Naučit se, jak produktivně realizovat určitou výukovou metodu, vyžaduje citlivost a schopnost posoudit, jakým způsobem a za jakým účelem lze tu kterou metodu produktivně využít (tamtéž). Nestačí tedy převzít metodu, ale zhodnotit její možnosti a př́nos $\mathrm{v}$ konkrétním výukovém kontextu. $\mathrm{V}$ podobném smyslu hovoří Lunenberg \& Korthagen (2009) o praktické moudrosti coby schopnosti uvědomit si podstatné prvky té které výukové situace a na jejich základě aplikovat vhodné postupy. 
Je zřejmé, že pokud má být určitý program profesního vzdělávání učitelů účinný, je třeba, aby nejenom seznamoval učitele $s$ novými metodami či poznatky, ale aby též rozvíjel jejich praktickou moudrost. $\mathrm{V}$ námi realizovaném programu se patrně tento bod podařilo naplnit, a to díky důslednému reflektování jednotlivých lekcí, které učitelé $\mathrm{v}$ průběhu programu realizovali ( $\mathrm{k}$ bližším informacím o reflektivním prvku v projektu viz Šed’ová, 2016). K tomuto závěru nás vede zjištění, že účelnost ve výsledku nepoklesla, nýbrž vzrostla a že můžeme sledovat pozitivní statistický vztah mezi mírou účelnosti a stě̌̌ejním dialogickým indikátorem žákovských replik s argumenty. Ačkoli tato studie vypovídá o tom, že bezúčelné pasáže v našem projektu vznikaly v důsledku snahy učitelů implementovat postupy dialogického vyučování, svědčí také o tom, že napětí mezi účelností a indikátory bylo nakonec harmonizováno a sladěno - učitelé byli $s$ to vyhodnotit, kdy dialogické vyučování účelně využít, a kdy od něj naopak ustoupit. $V$ jedné z předchozích studií (Šed’ová et al., 2014) jsme vyslovili pochybnost, zda principy dialogického vyučování formulované Alexanderem (2006) nejsou přehnaně idealistickým konceptem, který komplikuje zavedení dialogického vyučování do praxe. $Z$ našich současných analýz však naopak vyplývá, že čím je výuka účelnější, tím více odpovídá ideálu dialogického vyučování. Soustředění pozornosti na obsah výuky a předcházení didaktickým formalismům má tudiž potenciál pozitivně katalyzovat změnu.

\section{LiterATURA}

Alexander, R. J. (2006). Towards dialogic teaching: Rethinking classroom talk. Cambridge: Dialogos.

Boyd, M. P., \& Markarian, W. C. (2011). Dialogic teaching: Talk in service of a dialogic stance. Language and Education, 25(6), 515-534.

Boyd, M. P., \& Markarian, W. C. (2015). Dialogic teaching and dialogic stance: Moving beyond interactional form. Research in Teaching of English, 49(3), 272-296.

De Vries, S., Jansen, E., \& van de Gift, W. (2013). Profiling teachers continuing professional development and the relation with their beliefs about learning and teaching. Teaching and Teacher Education, 33(1), 78-89.

Gayle, B. M., Preiss, R. W., \& Allen, M. (2006). How effective are teacher-initiated classroom questions in enhancing student learning? In B. M. Gayle, R. W. Preiss, N. Burrell \& M. Allen (Eds.), Classroom communication and instructional processes (s. 279-293). Mahwah: Lawrence Erlbaum Associates.

Hammond, J. (2016). Dialogic space: Intersections between dialogic teaching and systemic functional linguistics. Research Papers in Education, 31(1), 5-22.

Hejný, M., \& Kuřina, F. (2009). Ditě, škola a matematika. Praha: Portál.

Herbel-Eisenmann, B. A., Steele, M. D., \& Cirillo, M. (2013). (Developing) teacher discourse moves: A framework for professional development. Mathematics Teacher Educator, 1(2), $181-196$. 
Hník, O. (2014). Didaktika literatury: výzvy oboru. Praha: Karolinum.

Hník, O. (2015). Didaktika literatury: od polemických diskursů po formování samostatného oboru. In I. Stuchlíková, T. Janík, J. Slavík, M. Píšová, Z. Beneš, H. Čtrnáctová, ... N. Vondrová, Oborové didaktiky: bilance a perspektivy (s. 41-66). Brno: Masarykova univerzita.

Janík, T., et al. (2013). Kvalita (ve) vzdèláváni: obsahově zaměrený prístup ke zkoumáni a zlepšováni výuky. Brno: Masarykova univerzita.

Lefstein, A. (2010). More helpful as problem than solution: Some implications of situating dialogue in classrooms. In K. Littleton \& C. Howe (Eds.), Educational dialogues: Understanding and promoting productive interaction (s. 171-190). London: Routledge.

Lefstein, A., \& Snell, J. (2014). Better than best practice: Developing teaching and learning through dialogue. London: Routledge.

Lehesvuori, S., \& Viiri, J. (2015). Od teorie k praxi: Od plánování dialogického vyučování $\mathrm{k}$ jeho reflexi. Studia paedagogica, 20(2), 9-31.

Lehesvuori, S., Viiri, J., Rasku-Puttonen, H., Moate, J., \& Helaakoski, J. (2013). Visualizing communication structures in science classrooms: Tracing cumulativity in teacher-led whole class discussions. Journal of Research in Science Teaching, 50(8), 912-939.

Lemke, J. L. (1990). Talking science: Language, learning, and values. Norwood: Ablex.

Lunenberg, M., \& Korthagen, F. (2009). Experience, theory and practical wisdom in teaching and teacher education. Teachers and Teaching: Theory and Practice, 15(2), 225-240.

Lyle, S. (2008). Dialogic teaching: Discussing theoretical context and reviewing evidence from classroom practice. Language and Education, 22(3), 222-240.

Maňák, J. (2007). Modelování kurikula. Orbis scholae 2(1), 40-53.

Martin, J. R. (1993). Literacy in science: Learning to handle text as technology. In J. R. Martin \& M. A. K. Halliday (Eds.), Writing science: Literacy and discursive power (s. 184-222). Pittsburgh: University of Pittsburgh Press.

Molinari, L., \& Mameli, C. (2013). Process quality of classroom discourse: Pupil participation and learning opportunities. International Journal of Educational Research, 62(1), 249-258.

Muhonen, H., Rasku-Puttonen, H., Pakarinen, E., Poikkeus, A., \& Lerkkanen, M. (2017). Knowledge-building patterns in educational dialogue. International Journal of Educational Research, 81, 25-37.

Nurkka, N., Viiri, J., Littleton, K., \& Lehesvuori, S. (2014). A methodological approach to exploring the rhythm of classroom discourse in a cumulative frame in science teaching. Learning, Culture and Social Interaction, 3(1), 54-63.

Nystrand, M., Gamoran, A., Kachur, R., \& Prendergast, C. (1997). Opening dialogue. Understanding the dynamics of language and learning in the english classroom. New York: Teachers College Press.

Nystrand, M., Wu, L. L., Gamoran A., Zeiser, S., \& Long, D. (2001). Questions in time: Investigating the structure and dynamics of unfolding classroom discourse. Cela research report number 14005. New York: The National Research Center on English Learning \& Achievement. 
Pimentel, S. D., \& McNeill, K. L. (2013). Conducting talk in secondary science classrooms: Investigating instructional moves and teachers' beliefs. Science Education, 97(3), 367-394. Pitha, P., et al. (1992). Úvod do výchovy $k$ občanstvi: knižka pro učitele a veřejnost. Praha: AVED. Průcha, J., Walterová, E., \& Mareš, J. (2009). Pedagogický slovník. Praha: Portál. RVP ZP (2007). Rámcový vzdělávaci program pro základni vzdẽlávání. Praha: VÚP.

Reznitskaya, A., \& Gregory, M. (2013). Student thought and classroom language: Examining the mechanism of change in dialogic teaching. Educational Psychologist, 48(2), 114-133.

Scott, P. (2008). Talking a way to understanding in science. In N. Mercer (Ed.), Exploring talk in schools: Inspired by the work of Douglas Barnes (s. 17-37). London: SAGE.

Sfard, A. (2008). Thinking as communicating. New York: Cambridge University Press.

Slavík, J., Janík, T., Jarníková, J., \& Tupý, J. (2014). Zkoumání a rozvíjení kvality výuky v oborových didaktikách: metodika 3 A mezi teorií a praxí. Pedagogická orientace, 24(5), $721-752$.

Staněk, A. (2007). Výchova k občanství a evropanství. Olomouc: Nakladatelství Olomouc.

Staněk, A. (2015). Didaktika společenských věd. In I. Stuchlíková, T. Janík, J. Slavík, M. Píšová, Z. Beneš, H. Čtrnáctová, ... N. Vondrová, Oborové didaktiky: bilance a perspektivy (s. 327-359). Brno: Masarykova univerzita.

Reznitskaya, A., \& Wilkinson, I. (2015). Professional development in dialogic teaching: Helping teachers promote argument literacy in their classrooms. In D. Scott \& E. Hargreaves (Eds.), The SAGE handbook of learning (s. 219-232). London: Sage.

Šed'ová, K. (2016). Reflexe jako nástroj změny komunikačního chování učitele: př́ípadová studie. Pedagogika, 66(4), 477-494.

Šed'ová, K., Švaříček, R., \& Šalamounová, Z. (2012). Komunikace ve školni trìdě. Praha: Portál. Šedová, K., Švaříček, R., Sedláček, M., \& Šalamounová, Z. (2014). On the way to dialogic teaching: Action research as a means to change classroom discourse. Studia paedagogica, 19(4), 9-43.

Šedová, K., Sedláček, M., \& Švaříček, R. (2016a). Teacher professional development as a means of transforming student classroom talk. Teaching and Teacher Education, 57, 14-25.

Šedová, K., Švařiček, R., Sedláček, M., \& Šalamounová, Z. (2016b). Jak se učitelé učí. Cestou profesního rozvoje $k$ dialogickému vyučování. Brno: Masarykova univerzita.

Štech, S. (2003). Vzdělávací programy mají umožnit poznání aneb Brána mysli otevřená. In A. Brabcová (Ed.), Brána muzea otevrená (s. 66-85). Praha: JUKO - Open Society Fund.

Twiner, A., Littleton, K., Coffin, C., \& Whitelock, D. (2014). Meaning making as an interactional accomplishment: a temporal analysis of intentionality and improvisation in classroom dialogue. International Journal of Educational Research, 63, 94-106.

Vygotsky, L. S. (1978). Mind in society: The development of higher psychological processes. Cambridge: Harvard University Press. 
Mgr. et Mgr. Bc. Zuzana Šalamounová, Ph.D.,

Masarykova univerzita, Filozofická fakulta, Ústav pedagogických véd;

e-mail:salamounova@phil.muni.cz

Doc. Mgr. Klára Šedová, Ph.D.,

Masarykova univerzita, Filozofická fakulta, Ústav pedagogických véd;

e-mail:ksedova@phil.muni.cz

Mgr. Martin Sedlácek, Ph.D.,

Masarykova univerzita, Filozofická fakulta, Ústav pedagogických véd;

e-mail:msedlace@phil.muni.cz

Mgr. Roman Švařičcek, Ph.D.,

Masarykova univerzita, Filozofická fakulta, Ústav pedagogických véd;

e-mail: svaricek@phil.muni.cz

\section{Příloha 1}

Plán realizovaného programu pro učitele.

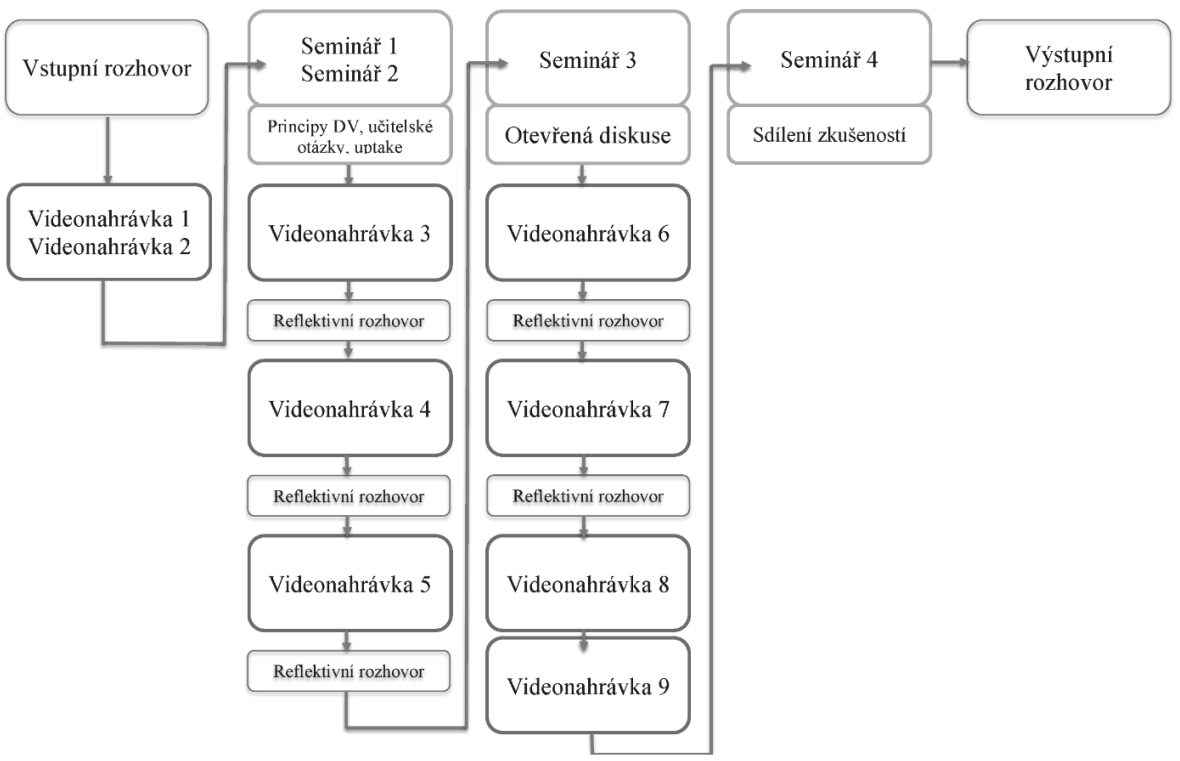




\section{Př́loha 2}

Transkripční pravidla (upraveno podle Lefstein \& Snell, 2014)

(.) krátká pauza (méně než jedna sekunda)

(1) delší pauza (č́slo vyjadřuje délku trvání v sekundách)

(n) nesrozumitelná část textu

(text) popis neverbální aktivity

[text] překrývající se řeč

text zdůraznění

TEXT zvýšení hlasitosti

ŠALAMOUNOVÁ, Z., ŠEĎOVÁ, K., SEDLÁČEK, M., ŠVAŘíČEK, R. The Problem of Purposefulness in Dialogic Teaching

This contribution is based on data gathered in an intervention research project in which eight teachers cooperated with four researchers on a professional development programme aimed at the implementation of features of dialogic teaching in their teaching practice. Dialogic teaching emphasises work with language and communication with pupils to stimulate their thinking and deepen their understanding (Alexander, 2006). The intervention proved to be successful in the sense that the modes of communication of both the teachers and their students changed. On the other hand, we noted during analysis of video-recorded classes that teachers included dialogic teaching without respecting the principle of purposefulness.

Consequently, in this contribution we provide a typology of situations in which teachers meet some formal indicators of dialogic teaching but violate the principle of purposefulness, and we explain what causes violations of the principle. Categories of such situations include the initiation of pointless guesses about theme, riddles, quasi-evocation of responses and quasicritical reflections, mere chatting, digressions into students' personal life, and setting tasks out of the students' reach.

We identify two causes of purposeless passages: thoughtless adoption of teaching methods and a deviation from the lesson plan which the teacher is unable to control. We then examine the relationship between the key indicator of argumentation in students' replies and the principle of purposefulness to identify how the presence of dialogic education is connected to effectiveness of teaching. Our findings show that if student replies involving arguments increase in number then the degree of purposefulness increases as well.

Keywords: dialogic teaching, principle of purposefulness, purposelessness of lesson, educational content, students' replies involving argumentation, interventional programme for teachers. 